\title{
Oil And Asset Classes Implied Volatilities: Investment Strategies And Hedging Effectiveness*
}

\author{
Nikolaos Antonakakis ${ }^{\dagger, \ddagger}$, Juncal Cunado ${ }^{\S}$, George Filis $₫$, David \\ Gabauer $^{\#, \$}$, and Fernando Perez de Gracia ${ }^{\S}$
}

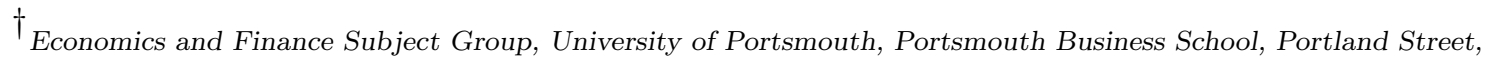
Portsmouth, PO1 3DE, United Kingdom. Tel: +44 (0)239284 4261. Email: nikolaos.antonakakis@port.ac.uk ${ }^{\ddagger}$ Department of Business and Management, Webster Vienna Private University, Praterstrasse 23, 1020 Vienna, Austria. Tel: +43-1-2699293-4373. Email: nikolaos.antonakakis@webster.ac.at, david.gabauer@webster.ac.at

$\S$ University of Navarra, Department of Economics, Pamplona 31080, Spain. Email: jcunado@unav.es, fgracia@unav.es

\# Software Competence Center Hagenberg, Data Analysis Systems, Softwarepark 21, 4232 Hagenberg, Austria. Tel: +43-7236-3343-875. Email: david.gabauer@scch.at

\$ohannes Kepler University, Institute of Applied Statistics, Altenbergerstraße 69, 4040 Linz, Austria. Tel: +43-732-2468-6806. Email: david.gabauer@jku.at

『 Department of Accounting, Finance and Economics, Bournemouth University, 89 Holdenhurst Road, Executive Business Centre, BH8 8EB, Bournemouth, United Kingdom.Email: gfilis@bournemouth.ac.uk
}

\begin{abstract}
Building on the increased interest in oil prices and other financial assets, this paper examines the dynamic conditional correlations among their implied volatility indices. We then proceed to the examination of the optimal hedging strategies and optimal portfolio weights for implied volatility portfolios between oil and fourteen asset volatilities, which belong to four different asset classes (stocks, commodities, exchange rates and macroeconomic conditions). The results suggest that the oil price implied volatility index (OVX) is highly correlated with the US and emerging stock market volatility indices, whereas the lowest correlations are observed with the implied volatilities of gold and the Euro/dollar exchange rate. Hedge ratios indicate that VIX is the least useful implied volatility index to hedge against oil implied volatility. Finally, we show that investors can benefit substantially by adjusting their portfolios based on the dynamic weights and hedge ratios obtained from the dynamic conditional correlation models, although a trade-off exists between the level of risk reduction and portfolio profitability.
\end{abstract}

Keywords: Hedging strategies; hedging effectiveness; volatility portfolios; oil prices; stock market indices

JEL codes: C32, F3, G12, Q43.

* Juncal Cuado and Fernando Perez de Gracia gratefully acknowledge financial support from the Ministerio de Economa y Competitividad (ECO2017-83183-R). George Filis acknowledges the support of the European Union's Horizon 2020 research and innovation programme, which has funded them under the Marie Sklodowska-Curie grant agreement No 746025. David Gabauer acknowledges that the research reported in this article has been partly funded by BMK, BMDW, and the Province of Upper Austria in the frame of the COMET Programme managed by FFG. 


\section{Introduction}

Since the increased financialisation of the oil market over the last 15 years, a growing literature has emerged examining the time-varying relationship and spillover effects among oil and financial markets (see, inter alia, Malik and Hammoudeh, 2007; Malik and Ewing, 2009; Filis et al., 2011; Arouri et al., 2011a,b, 2012; Sadorsky, 2012; Chkili et al., 2014; Broadstock and Filis, 2014; Degiannakis et al., 2014; Khalfaoui et al., 2015; Phan et al., 2016; Antonakakis et al., 2017; Maghyereh et al., 2017; Antonakakis et al., 2018b). Apart from the empirical evidence on the spillover effects between oil and financial markets, there are also policy makers, such as the IMF in their 2015 Spillover Report, who argue that "...policy actions in advanced economies and the decline in world oil prices last year have created a 'spillover-rich' environment..." (IMF, 2015).

Most studies in this line of research are performed primarily using the first moments (i.e. returns) of the variables under investigation, as well as, focusing only on the oil and stock markets (at aggregate, sectorial or firm level) nexus; whereas, there are only few studies that focus on the second moments, i.e. asset market volatilities (e.g., Malik and Hammoudeh, 2007; Arouri et al., 2011a,b, 2012; Antonakakis et al., 2018b).

For instance, Malik and Hammoudeh (2007) use a multivariate GARCH model to study the volatility transmission relationship between US equity market, global crude oil market and equity markets of Gulf economies. Their empirical findings support a significant volatility transmission among selected financial markets. In related papers, Arouri et al. (2011a) and Arouri et al. (2012), considering that industrial sectors may not all be equally dependent on oil, examine the volatility transmission between oil and sectorial stock market in Europe and the US. The results suggest a significant volatility spillover between oil and sector stock returns. Similarly, Arouri et al. (2011b) employ data from oil and stock returns from the GCC region and report a significant volatility spillover in most countries, especially during the Global Financial Crisis.

Interestingly enough all aforementioned studies examine solely the oil-stock market nexus. It is only Mensi et al. (2013) and Maghyereh et al. (2017) that also include other asset classes in their study, such as commodities and metals, showing increased return and volatility linkages between oil and commodities markets. 
Parallel to the growing interest in the spillover effects and time-varying interrelations between oil and stock markets, there is another strand of the literature that emerges simultaneously and this is related to the diversification strategies that investors could adopt when forming portfolios that combine oil and other asset classes.

Indicatively, Chang et al. (2011) calculate optimal hedge ratios from different multivaritate conditional variance models using Brent and WTI crude oil spot and futures data. Their results support that all four multivariate conditional variance models reduce the variance of the portfolio between oil spot and futures contracts. In addition, they show that the models perform better in the WTI market than the Brent market. Chkili et al. (2014) further find that investors can improve the risk-adjusted performance of their portfolios by exploiting the diversifying and hedging potential of the crude oil asset through taking appropriate actions in the crude oil futures markets.

Except from studies that assess the time-varying hedging strategies between oil spot and futures prices, other studies employ similar approach for portfolios comprising oil and financial assets. For instance, Mensi et al. (2015) examine time-varying hedging strategies between the USD/EUR exchange rate and alternative petroleum prices using bivariate Dynamic Conditional Correlation EGARCH (DCC-EGARCH) model with structural breaks. They show that more appropriate hedging and asset allocation strategies can be obtained using a time-varying framework. Basher and Sadorsky (2016) propose Asymmetric DCC (ADCC) and GO-GARCH models using different time series data of oil prices, emerging market stock returns, gold prices, bond prices and the VIX. For instance, they obtain that oil is the best asset to hedge emerging market stock prices. Khalfaoui et al. (2015) analyse the hedge ratio and hedge effectiveness across different time horizons following the methods of Kroner and Ng (1998) and Hammoudeh et al. (2010). Their results support that hedge ratios are different across scales and investors and financial markets participant should hold less stocks than crude oil.

Following the hedging approach proposed by Chang et al. (2011), Ewing and Malik (2016) employ the percentage reduction in variance to measure the hedging effectiveness. Their results show evidence of cross-market hedging and sharing of common information by financial market participants in the oil and stock markets. Wang and Liu (2016) also 
use the percentage reduction in variance to measure the hedging effectiveness (Chang et al., 2011). They show that crude oil risk can be better hedged by investing in stocks of oil-exporting countries than in those of oil-importing countries. Antonakakis et al. (2018b) show that the average hedge ratios in the oil price volatility do not change notably in the pre-, during and post-financial crisis periods.

Despite the wealth of literature in this line of research, there is an important gap that has been rather ignored, which relates to the investigation of the time-varying relationship and diversification strategies between oil price and financial assets' implied volatility indices. This importance stems from two facts. First, implied volatility indices, being forward-looking measures, are regarded as "fear indices" of the asset class they represent, and as such, examining their correlations over time could provide important information on how "fear" in one asset class may be propagated in other asset classes. This is particularly relevant currently, since the different asset classes have become closer interlinked with the oil market. Second, implied volatility indices represent investment assets, which have received increased attention by investors and portfolio managers in the recent years, hence the importance of examining their time-varying correlations and diversification strategies.

Against this backdrop, the aim of this paper is twofold. First, we compute the timevarying correlations between all the available implied volatility indices ${ }^{1}$ against the OVX index, which is the implied volatility index of the United States Oil Fund, which approximates the implied volatility of the WTI crude oil prices. Second, we compute the optimal hedging strategies, along with their hedging effectiveness and trading profitability, for two-asset portfolios comprised the OVX and each of the remaining implied volatility indices, using the estimated dynamic conditional correlations.

Our contributions can be described succinctly. First, unlike the previous literature, we investigate the time-varying correlations and optimal hedging strategies for implied volatility indices, which are investment assets, as they are based on specific Exchange Traded Funds (ETFs). Thus, our findings are of high relevance to investors and portfolio managers. Second, our data are not confined in the oil and stock market relationship, but

\footnotetext{
${ }^{1}$ We consider the implied volatility indices that are provided directly by the CBOE. Please refer to the data section (Section 2) for further details.
} 
rather we use the implied volatility indices from oil prices and five other assets classes, namely stock markets (both from the US and emerging economies), energy commodities, precious metals, exchange rates and bonds. Third, we extend the evaluation of the hedging strategies beyond the hedging effectiveness (i.e., percentage of risk reduction compared to single asset portfolios), so as to incorporate the profitability of investors using the different strategies. We note that the current literature solely focuses on the evaluation of hedging strategies based on their hedging effectiveness. Finally, to the best of our knowledge this study is the first which provides a test statistic for the hedging effectiveness which opens avenues for further research and is highly valuable for investors and portfolio managers. We provide different statistics and evaluate them by using Monte Carlo simulation specific scenarios for the financial markets regarding outliers and distributional assumptions.

Our study employs time series data of daily implied volatility indices over the period 2011-2018, which covers the periods on geopolitical unrest in the Middle-East, as well as, the decline in oil prices initiated in June 2014. The 2014 large decline in the oil prices provide a "special case study of oil shock" to investigate the different asset classes implied volatility indices sensitivity of oil price implied volatility.

In short, our findings show that there is a strong positive association between OVX and the remaining implied volatility indices, as suggested by the dynamic conditional correlations, although the highest correlations are observed with the US stock markets and the emerging stock markets. Furthermore, the results from the optimal hedge ratio and optimal portfolio weight strategies suggest that investors should follow a dynamic diversification strategy between OVX and any of the other assets' implied volatilities, although the highest risk reduction is achieved by the former strategy. By contrast, though, the optimal portfolio strategy is the only one that yields positive cumulative returns over our sample period. These findings suggest that investors, who are interested in portfolio comprised OVX and any of the other assets' implied volatilities, have a tradeoff between the required level of risk reduction and portfolio returns.

The remainder of the paper is structured as follows. Section 2 discusses the methodology and describes the dataset. Empirical results are presented in Section 3. Finally, Section 4 concludes the study. 


\section{Dataset and Empirical Methodology}

Our dataset consists of daily data from fifteen implied volatility indices which can be grouped into five different assets classes, namely, energy commodities, stock markets, precious metals, exchange rates and bond market. The specific series are the implied volatility indices of CBOE Crude Oil ETF (OVX), Euro/dollar currency (EVZ), Gold ETF (GVZ), Silver ETF (VXSLV), Russell 2000 (RVX), S\&P 500 (VIX), Dow Jones Industrial Average (VXD), NASDAQ-100 (VXN), EFA (Europe, Australia, Asia and the Far East) ETF (VXEFA), Emerging Markets ETF (VXEEM), Brazil ETF (VXEWZ), China ETF (VXFXI), CBOE 10-Year Treasury Note (VXTYN), CBOE Equity VIX on Goldman Sachs (VXGS) and the CBOE Energy Sector ETF (VXXLE). We directly obtain the implied volatility indices from the Federal Reserve Economic Data of the Federal Reserve Bank of St. Louis (FRED). The period of the study spans from 16th March 2011 to 28th December 2018 and it is dictated by the common data availability of the series.

Descriptive statistics of the implied volatilities indices, as well as, their plots, are shown in Table 1 and Figure 1, respectively, whereas Table 2 refers to the descriptive statistics of the returns of the implied volatilities which are calculated as follows: $y_{t}=\log \left(x_{t}\right)-\log \left(x_{t-1}\right)$. Based on Table 1, the daily average implied volatility varies according to the index, with the lower being the EVZ (9.871\%) and the highest being the OVX. High average daily volatility is also exhibited by VXEFA and VXFXI. The latter implied volatility index, along with OVX and VXTYN exhibits very high volatility. Furthermore, almost all implied volatility series present excess kurtosis and are positively skewed. Finally, all series are not normally distributed, as it is evident by the Jarque-Bera test. The ERS test (known as the ADF-GLS test) proposed by Stock et al. (1996) is significant for all series, suggesting that all implied volatility series are stationary. Finally, it is evident that our series are subject to autocorrelation and exhibit ARCH effects (see, LB(20) and LiMak(20) tests, respectively). Similar observations are shown in Table 2.

[Insert Table 1 around here]

[Insert Table 2 around here]

Figure 1 also confirms the increased volatility of OVX and EFA implied volatility 
indices. Furthermore, we show that VIX also demonstrates high values during 2011, whereas the OVX, apart from the late 2011, it fluctuates at very high values during the period 2014-2015, which is the period of the most recent oil price collapse, as well as, in 2016, which reflects the disagreement between OPEC and non-OPEC countries to curb oil production due to declining demand.

[Insert Figure 1 around here]

Having analysed the dataset of this study, we proceed with the description of our empirical analysis, which consists of the following two steps. In the first step, we estimate the time-varying correlations between oil price implied volatility and eleven other implied volatility indices, so as to assess the dynamic linkages between the aforementioned series. Subsequently, we use this information for the construction of the optimal investment strategies.

\subsection{DCC-GARCH t-Copula}

We are estimating a mixed DCC-GARCH t-Copula model a la Antonakakis et al. (2018a). With this model we estimate time-varying variance-covariances and time-varying conditional correlations. Generally, the model can be formulated as follows:

$$
\boldsymbol{x}_{t}=\boldsymbol{H}_{t}^{-1 / 2} \boldsymbol{z}_{t} \quad \boldsymbol{z}_{t} \sim \boldsymbol{t}_{\eta}
$$

where $\boldsymbol{H}_{t}$ is the time-varying variance-covariance matrix, $\boldsymbol{z}_{t}$ are the standardized residuals, and $\boldsymbol{t}_{\eta}$ is the a N-dimensional multivariate Student's $\mathrm{t}$ distribution with $\eta$ degrees of freedom.

According to Joe (1997), copulas are very flexible tools which allow to model dependencies across random variables. According to to Sklar (1959) theorem, there is a linkage between copula functions and joint distribution functions of random variables. Let $F_{X_{1}, \ldots, X_{N}}$ be the joint distribution function of the random variables $X_{1}, \ldots, X_{N}$ with continuous marginal distribution functions $F_{X_{1}}, \ldots, F_{X_{N}}$. In this case, there exists a unique 
N-dimensional copula distribution function $C$ which can be written as,

$$
F_{X_{1}, \ldots, X_{N}}=C\left(F_{X_{1}}\left(x_{1}\right), \ldots, F_{X_{N}}\left(x_{N}\right)\right)
$$

where $F_{X_{i}}=u_{i}, i=1, \ldots, N$ are uniformly distributed. This leads to:

$$
C\left(u_{1}, \ldots, u_{N}\right)=F_{X_{1}, \ldots, X_{N}}\left(F_{X_{1}}^{-1}\left(u_{1}\right), \ldots, F_{X_{N}}^{-1}\left(u_{N}\right)\right) .
$$

Patton (2006) has shown that copulas can also be based on conditional distributions on which our estimated DCC-GARCH t-copula model is based upon:

$$
\begin{aligned}
C\left(u_{1}, \ldots, u_{N} \mid \boldsymbol{R}_{t}, \eta\right) & =\boldsymbol{t}_{\eta}\left(F_{X_{1}}^{-1}\left(u_{1} \mid \bullet_{1}\right), \ldots, F_{X_{N}}^{-1}\left(u_{N} \mid \bullet_{N}\right)\right) \\
& =\int_{-\infty}^{F_{1}^{-1}\left(u_{1}\right)} \cdots \int_{-\infty}^{F_{N}^{-1}\left(u_{N}\right)} \frac{\Gamma\left(\frac{\eta+N}{2}\right)}{\Gamma\left(\frac{\eta}{2}\right)(\eta \pi)^{N / 2}\left|\boldsymbol{R}_{t}\right|^{1 / 2}}\left(1+\frac{1}{\eta} \boldsymbol{z}_{t}^{\prime} \boldsymbol{R}_{t}^{-1} \boldsymbol{z}_{t}\right)^{(\eta+N) / 2} d z_{1}, \ldots, d z_{N},
\end{aligned}
$$

where $F_{X_{i}}^{-1}\left(u_{i} \mid \bullet_{i}\right)$ represents the conditional distribution and $\bullet \bullet_{i}$ represents the estimated parameters of the selected univariate GARCH model. This demonstrates that the underlying unvariate GARCH models of the DCC-GARCH t-copula are allowed to have different marginal distributions.

In a next step, we use the fundamental DCC-GARCH concept of Engle (2002) to calculate time-varying variance-covariances and dynamic conditional correlations, $\boldsymbol{R}_{t}$. Hereby, the time-varying variance-covariances are constructed as follows:

$$
\boldsymbol{H}_{t}=\boldsymbol{D}_{t} \boldsymbol{R}_{t} \boldsymbol{D}_{t}
$$

where $\boldsymbol{D}_{t}=\operatorname{diag}\left(h_{11 t}, \ldots, h_{N N t}\right)$, which follow a univariate GARCH process. To find the most appropriate univariate GARCH model we estimate all restricted family GARCH 
models (Hentschel, 1995)2 . The family GARCH model can be formulated by:

$$
h_{i i t}^{\lambda_{i}}=\omega_{i}+\alpha_{i} h_{i i t-1}^{\lambda_{i}}\left(\left|z_{i t-1}-\zeta_{i}\right|-\gamma_{i}\left(z_{i t-1}-\zeta_{i}\right)\right)^{\delta_{i}}+\beta h_{i i t-1}^{\lambda_{i}} .
$$

After calculating the time-varying variance-covariances, we compute the the dynamic conditional correlations, $\boldsymbol{R}_{t}$, which are based on the standardized residuals' conditional variance-covariances, $\boldsymbol{Q}_{t}$, that are assumed to follow a $\operatorname{GARCH}(1,1)$ model Engle (2002):

$$
\begin{aligned}
\boldsymbol{Q}_{t} & =(1-a-b) \overline{\boldsymbol{Q}}+a \boldsymbol{z}_{t-1} \boldsymbol{z}_{t-1}^{\prime}+b \boldsymbol{Q}_{t-1} \\
\boldsymbol{R}_{t} & =\operatorname{diag}\left(\boldsymbol{Q}_{t}\right)^{-1 / 2} \boldsymbol{Q}_{t} \operatorname{diag}\left(\boldsymbol{Q}_{t}\right)^{-1 / 2}
\end{aligned}
$$

where $\overline{\boldsymbol{Q}}$ is the unconditional variance-covariance matrix of the standardized residuals, $a$ is the shock parameter and $b$ is the persistency parameter. A stationary process requires that $a>0, b>0$ and $a+b<1$.

Since $\boldsymbol{R}_{t}$ is a multivariate Pearson correlation coefficient that fully defines the multivariate normal dependence structure, however is very restrictive and cannot capture tail dependencies, we calculate an alternative measure: Kendall's $\tau$ (Kruskal, 1958), This measure is based on rank correlations and is not as restrictive as the Pearson correlation coefficient. According to Lindskog et al. (2003), the Kendall and the Pearson correlation coefficient share a one-to-one relationship which can be written as follows:

$$
\tau\left(\epsilon_{i}, \epsilon_{j}\right)=\frac{2}{\pi}\left[1-\sum_{\epsilon \in \mathbb{R}} P\left(X_{i}=x\right)^{2}\right] \arcsin \left(R_{i j t}\right) .
$$

\subsection{Dynamic Hedge Ratios}

Furthermore, we are interested in hedging costs and portfolio diversification. Thus, we calculate hedge ratios a la Kroner and Sultan (1993) and optimal portfolio weights a la Kroner and $\mathrm{Ng}$ (1998). Hedge ratios determine the costs of hedging a 1 USD long position

\footnotetext{
${ }^{2}$ We are using the GARCH selection criterion introduced by Antonakakis et al. (2018a) and extend their approach by taking under consideration even more models. This can be done conveniently by using the family GARCH model which is an omnibus model including the GARCH (Bollerslev, 1986), IGARCH (Engle and Bollerslev, 1986), EGARCH (Nelson, 1991), AVGARCH (Schwert, 1990), TGARCH (Zakoian, 1994), GJRGARCH (Glosten et al., 1993), NGARCH (Higgins et al., 1992), NAGARCH (Engle and Ng, 1993), and APARCH (Ding et al., 1993) as special cases. The interested reader is referred to Ghalanos (2012, 2018).
} 
in variable $i$ with a $\beta_{i j t}$ USD short position in variable $j$. This can be calculated by

$$
\beta_{i j t}=\frac{h_{i j t}}{h_{j j t}}
$$

where $h_{i j t}$ is the conditional covariance of variable $i$ and $j$. This implies that higher conditional variances lead to lower long position hedging costs whereas an increase in the conditional covariances will increase the long position hedging costs.

\subsection{Dynamic Portfolio Weights}

The portfolio weights between variable $i$ and $j$ are computed by

$$
w_{i j t}=\frac{h_{j j t}-h_{i j t}}{h_{i i t}-2 h_{i j t}+h_{j j t}} .
$$

However, this calculation allows for weights above one or below zero. Since we are only interested in long-positions, we impose restrictions on the weights so that they cannot exceed one or deceed zero:

$$
w_{i j t}= \begin{cases}0 & \text { if } w_{i j t}<0 \\ w_{i j t} & \text { if } 0 \leq w_{j i t} \leq 1 \\ 1 & \text { if } w_{i j t}>1\end{cases}
$$

where $w_{i j t}$ is the weight of variable $i$ in a 1 USD portfolio of two variable $i$ and $j$ at time $t$. The second weight regarding variable $j$ is $w_{j i t}=\left(1-w_{i j t}\right)$.

\section{$2.4 \quad$ Hedging Effectiveness}

Finally, it is essential to calculate the effectiveness of the hedging and portfolio techniques. This is done by computing the hedging effectiveness a la Ederington (1979) which can be 
written as

$$
\begin{aligned}
r_{\beta} & =x_{i t}-\beta_{j i t} x_{j t}, \\
r_{w} & =w_{i j t} x_{i t}+\left(1-w_{i j t}\right) x_{j t}, \\
H E_{i} & =1-\frac{\operatorname{Var}\left(r_{w, \beta}\right)}{\operatorname{Var}\left(r_{\text {unhedged }}\right)},
\end{aligned}
$$

where $\operatorname{Var}\left(r_{\text {unhedged }}\right)$ denotes the variance of the unhedged position between variable $i$ and $j$ and $\operatorname{Var}\left(r_{w, \beta}\right)$ is the hedged portfolio variance either from the optimal hedge ratio or the optimal portfolio weight strategy. Intuitively speaking, $H E_{i}$ represents the percent reduction in the variance of the unhedged position. The higher $H E_{i}$ is the larger is the risk reduction. To the best of our knowledge this is the first paper to introduce a test statistic regarding the $\mathrm{HE}$ which informs us if the reduction in the risk is significant or not. Since the second part of the $\mathrm{HE}$ is nothing more than a variance ratio we can estimate if the reduction is significant or not by using an F-statistic. However, the power of an F-statistics is pretty low when the underlying variable is not normally distributed - which is often the case when it comes to financial series - hence, such statistics would not be sufficient. To find the most appropriate test statistic for our HE we conduct a Monte Carlo simulation under different scenarios which should reflect the characteristics of financial series better. Given the fact that we are often dealing with fat tails, excess events and with survivor bias (skewed distributions) in the financial market, we are simulating the deviance ratio of a normal, Student's $t$ and generalized error distribution, their skewed versions and with and without outliers to check which test statistic is the most appropriate one. Table 3 illustrates that the Brown and Forsythe (1974) test outperforms the parametric F test, the Levene (1960) test, and the nonparametric Fligner and Killeen (1976) test. As expected the F-test reveals low power when the underlying variable is not normally distributed and the Levene and Fligner-Killeen test have low power when we have a skewed distribution, whereas the Brown \& Forsyth test has none of the aforementioned issues. Hence, the Brown \& Forsyth test is used to estimate whether the variance reduction using one of our investment techniques is successful or not.

[Insert Table 3 around here] 


\section{Empirical Results}

\subsection{Dynamic Conditional Correlations and Hedging Strategies}

Table 4 and Figure 2 show the dynamic conditional correlations between the implied volatility indices of oil and each of the selected assets from the DCC-GARCH t-Copula model. The dynamic conditional correlations suggest a strong association between these implied volatilities. The main characteristic of all corrections is that even though they tend to fluctuate at the positive region with an average correlation of about 0.4 , there are clear peaks and troughs. The positive correlations are anticipated given that there is a clear 'contagion' effect that is observed in implied volatilities and has been documented in previous studies (see, for instance, King and Wadhwani, 1990; Äijö, 2008; Liu et al., 2013).

Table 4 and Figure 2 also confirm that the highest correlations are mainly exhibited with the US stock markets (RVX, VIX, VXN) and the emerging markets (VXEEM). Another interesting finding is the low correlations that are observed between OVX and GVZ, EVZ and VXXLE. The latter findings are not in line with Ewing and Malik (2013) and Liu et al. (2013) who show a higher correlation figures between oil price volatility and gold or Euro/dollar volatilities. This can be attributed to the fact that Ewing and Malik (2013) and Liu et al. (2013) use a limited number of assets, contrary to the present study that considers a much wider set of implied volatility indices so as to capture their full dynamics.

[Insert Table 4 around here]

[Insert Figure 2 around here]

Having documented that there is indeed strong and time-varying relationship between the implied volatility returns of oil and the remaining assets, it is important to proceed to the examination of diversification strategies. In our study, we use two main strategies, namely optimal hedge ratios and optimal portfolio weights. We should note that we only assess the ability of implied volatility indices to offer hedging to investors that take a long position in the OVX, as well as, the OVX hedging capability when an investor takes a 
long position in any of the remaining implied volatility indices. Similarly, in the optimal portfolio weights strategy we only consider two-asset portfolios comprised by OVX and one additional implied volatility index.

Table 5 includes the basic statistics of the optimal hedge ratios for the aforementioned long/short positions. The median value of the hedge ratio between a long position in OVX and short position in the other implied volatilities range between 23 and 47 cents indicating that the cheapest hedge for the $\$ 1$ long position in OVX is obtained with VXXLE (23 cents), followed by VXGS (24 cents), GVZ and EVZ (26 cents) and VIX (28 cents), while the most expensive with VXN (47 cents). The latter evidence indicates that VXN is the least useful index to hedge against OVX. Furthermore, it is important to highlight that the exchange rate and precious metals implied volatility indices are cheaper hedging assets compared to the majority of stock market implied volatilities. Similarly, the hedging cost of a $\$ 1$ long position in each of the selected implied volatility indices using a short position in the OVX, also present some variation. For instance, OVX provides the cheapest hedge for $\$ 1$ long position in VXXLE (23 cents) and EVZ (25 cents), whereas 68 and 67 cents of the dollar are required to hedge $\$ 1$ dollar in VIX and VXN, respectively. Thus, we can observe that OVX could be particularly useful to hedge long positions in VXXLE, EVZ, VXFXI and GVZ.

[Insert Table 5 around here]

Table 5 further suggests that these optimal hedge ratios are not constant over time, as depicted by the standard deviation and the $5 \%$ and $95 \%$ percentiles. The later finding is also confirmed in Figure 3, which demonstrates the time-varying behavior of the optimal hedge ratios, suggesting that investors should be employing a dynamic rather than static hedging strategy. The most volatile hedge ratios are observed when a long position in OVX is hedged with one of the stock market implied volatility indices and more apparent with US stock indices of VXN and VXFXI. Nevertheless, we should highlight the fact that we cannot really document a material difference in the standard deviations of the hedge ratios for a long position in the OVX. On the other hand, the hedge ratios when OVX is the hedge asset seem to be more volatile. For instance, there is a high variability in the hedge ratios between VIX/OVX and VXD/OVX, whereas the reverse is evident for 
EVZ/OVX and VXXLE/OVX. Thus, investors who hedge their long position in the EVZ and VXXLE using the OVX do only benefit from a cheap hedge but also from a relative stable ratio.

Finally, Figure 3 reveals that in many cases there is a peak in the hedge ratios during the period 2015-16. A plausible explanation can be found in a series of economic events, with the most important being the contraction of the Japanese economy, the negative developments in the Greek debt crisis and the Brexit vote. The latter two events were also responsible for the global stock market sell-off that was observed in 2015-2016.

[Insert Figure 3 around here]

An alternative diversification strategy to optimal hedge ratios is the optimal portfolio weights. The results of the dynamic optimal portfolio weights for two-asset portfolios comprising of oil and one of the remaining implied volatilities are presented in Table 6 .

[Insert Table 6 around here]

The median weight reflects the dollar cents that need to be invested in OVX in any $\$ 1$ portfolio. For instance, in the OVX/GVZ portfolio, 59 cents should be invested in OVX and 41 cents in GVZ. For the majority of the portfolios OVX assumes the highest weight (with the only exceptions being the portfolios comprised OVX/EVZ, and OVX/VXFXI). As in the case of optimal hedge ratios, the optimal portfolio weights also exhibit a timevarying character, as shown by the standard deviation and 5\%/95\% percentiles of Table 6 , as well as, Figure 4. Once again, the dynamic character of this strategy further confirms the need for active portfolio rebalancing, rather than the adoption of a static approach (e.g., buy and hold).

[Insert Figure 4 around here]

In order to make suggestion of which strategy in implied volatility indices should be followed by investors, we need to assess the different strategies according to two criteria, namely, (i) their hedging effectiveness and (ii) their profitability. 
Hedging effectiveness shows the risk reduction that investors can achieve based on a hedged position either using the dynamic portfolio weight or dynamic hedge ratio strategies, compared to an unhedged position in the OVX. The results in Table 7 suggest that in all cases investing in the OVX makes someone better off than hedge their position using a dynamic hedge ratio strategy. Even more, we show that the highest effectiveness is achieved with VXGS and VIX, providing evidence that there are not only among the cheapest hedges (as shown in Table 5) but also among the most effective.

\section{[Insert Table 7 around here]}

Finally, we calculate the cumulative profits of the aforementioned diversification strategies for the period 2011-2018, which are presented in Figure 5 and Table 8. For robustness purposes we do not present only the cumulative profits from the dynamic portfolio weights and dynamic optimal hedge ratios but we also include the constant portfolio weights based on the median of the portfolio weights, the equally weighted portfolio and the buy and hold (unhedged) strategy.

[Insert Table 8 around here]

[Insert Figure 5 around here]

It is evident from Figure 5 and Table 8 that the only diversification strategy that yield positive cumulative returns is the dynamic portfolio weights. This finding is interesting since it illustrates the superiority of the dynamic portfolio weights regarding profits. The highest profits are observed in portfolios which consist of the OVX and VIX, VXD and VXSLV. Furthermore, someone should keep in mind that hedging a position should reduce the risk of an investor and hence its fundamental goal goal is reached as indicated by Table $7)$.

\section{Concluding Remarks}

This paper employs the DCC-GARCH t-Copula (Patton, 2006) to examine the dynamic conditional correlation among the implied volatilities of oil and fourteen indices that are 
related to five different assets classes, i.e. energy commodities, stock markets, precious metals, exchange rates and bonds. We use daily data from 16th March, 2011 to 28th December, 2018. In addition, we study optimal hedging strategies and optimal portfolio weights for pair variables using the hedge ratios and the optimal portfolio weights initially proposed by Kroner and Sultan (1993) and Kroner and Ng (1998), respectively.

The optimal hedge ratios and optimal portfolio weights strategies, based on the conditional variances and covariances of the DDC-GARCH t-Copula, report that they are indeed time-varying, and hence a dynamic portfolio rebalancing is suggested to investors. More importantly, we show that the most effective hedging strategy for OVX is the optimal hedge ratios compared to the optimal portfolio weights. Nevertheless, hedging effectiveness considers solely the risk profile of the portfolio. Examining the cumulative profit profile of these strategies we maintain that it is mainly the optimal portfolio weights strategy that yields positive returns over the period of the study. This highlights the fact that the most effective diversification strategy is not necessarily the most profitable one.

Furthermore, we introduced a test statistic for the hedging effectiveness measure of Ederington (1979). Until now this measure has been reported in multiple studies the reduction of the unhedged position's variance without being able to illustrate whether this variance reduction has been significant or not. This study has shown that the hedging effectiveness measure follows an F-distribution given that the variables under consideration are normally distributed. As this distributional assumption is often rejected in finance as variables have often fat tails, we have conducted multiple Monte Carlo simulations with various distributional assumptions which led to the conclusion that the Brown \& Forsyth test is the best among alternatives.

Overall, our empirical evidence provides new insights regarding the time-varying correlations and optimal hedging strategies between the implied volatilities of the oil prices and different asset classes, which have implications for practitioners, commodity and institutional investors, portfolio and risk managers. First, the paper highlights the importance of the dynamic portfolio rebalancing between OVX and the remaining implied volatilities, as well as, dynamic hedge ratio approach, as opposed to passive investment strategies. Furthermore, we show that investors who are primarily interested in the portfolio returns 
comprising OVX and another implied volatility index, they should rebalance their portfolios using a dynamic weighting strategy. By contrast, should they be primarily interested in reducing their risk, then the dynamic hedge ratios would be the preferred strategy. Finally, our findings suggest that investors should allocate, on average, the largest part of their funds in the OVX when forming their implied volatility portfolios, whereas, should they want to hedge their long or short OVX positions, the preferred assets are the implied volatility of the CBOE energy sector, gold and the EUR/USD currency.

These results open several avenues for further research. The most important being the ex-ante analysis of the aforementioned strategies, based on a forecasting exercise. Finally, we want to stress out that we have slightly extended the methodology Antonakakis et al. (2018a) provided by including NARCH, NGARCH and APARCH models and provided the hedging literature with a powerful test statistic for the hedging effectiveness indicator which is of major importance in the field of portfolio and risk management.

\section{References}

Äijö, J. (2008). Implied Volatility Term Structure Linkages Between VDAX, VSMI And VSTOXX Volatility Indices. Global Finance Journal, 18(3):290-302.

Antonakakis, N., Chatziantoniou, I., and Filis, G. (2017). Oil Shocks And Stock Markets: Dynamic Connectedness Under The Prism Of Recent Geopolitical And Economic Unrest. International Review Of Financial Analysis, 50:1-26.

Antonakakis, N., Chatziantoniou, I., and Gabauer, D. (2018a). European Currency CoMovements And Contagion: Evidence From A Bayesian TVP-(Pseudo) FAVAR Model.

Antonakakis, N., Cunado, J., Filis, G., Gabauer, D., and De Gracia, F. P. (2018b). Oil Volatility, Oil And Gas Firms And Portfolio Diversification. Energy Economics, 70:499515.

Arouri, M. E. H., Jouini, J., and Nguyen, D. K. (2011a). Volatility Spillovers Between Oil Prices And Stock Sector Returns: Implications For Portfolio Management. Journal Of International Money And Finance, 30(7):1387-1405.

Arouri, M. E. H., Jouini, J., and Nguyen, D. K. (2012). On The Impacts Of Oil Price Fluctuations On European Equity Markets: Volatility Spillover And Hedging Effectiveness. Energy Economics, 34(2):611-617.

Arouri, M. E. H., Lahiani, A., and Nguyen, D. K. (2011b). Return And Volatility Transmission Between World Oil Prices And Stock Markets Of The GCC Countries. Economic Modelling, 28(4):1815-1825.

Basher, S. A. and Sadorsky, P. (2016). Hedging Emerging Market Stock Prices With Oil, Gold, VIX, And Bonds: A Comparison Between DCC, ADCC And GO-GARCH. Energy Economics, 54:235-247. 
Bollerslev, T. (1986). Generalized Autoregressive Conditional Heteroskedasticity. Journal Of Econometrics, 31(3):307-327.

Broadstock, D. C. and Filis, G. (2014). Oil Price Shocks And Stock Market Returns: New Evidence From The United States And China. Journal Of International Financial Markets, Institutions And Money, 33(C):417-433.

Brown, M. B. and Forsythe, A. B. (1974). Robust Tests For The Equality Of Variances. Journal Of The American Statistical Association, 69(346):364-367.

Chang, C.-L., McAleer, M., and Tansuchat, R. (2011). Crude Oil Hedging Strategies Using Dynamic Multivariate GARCH. Energy Economics, 33(5):912-923.

Chkili, W., Hammoudeh, S., and Nguyen, D. K. (2014). Volatility Forecasting And Risk Management For Commodity Markets In The Presence Of Asymmetry And Long Memory. Energy Economics, 41:1-18.

Degiannakis, S., Filis, G., and Kizys, R. (2014). The Effects Of Oil Price Shocks On Stock Market Volatility: Evidence From European Data. Energy Journal, 35(1):35-56.

Ding, Z., Granger, C. W., and Engle, R. F. (1993). A Long Memory Property Of Stock Market Returns And A New Model. Journal Of Empirical Finance, 1(1):83-106.

Ederington, L. H. (1979). The Hedging Performance Of The New Futures Markets. Journal Of Finance, 34(1):157-170.

Engle, R. (2002). Dynamic Conditional Correlation. Journal Of Business And Economic Statistics, 20(3):339-350.

Engle, R. F. and Bollerslev, T. (1986). Modelling The Persistence Of Conditional Variances. Econometric Reviews, 5(1):1-50.

Engle, R. F. and Ng, V. K. (1993). Measuring And Testing The Impact Of News On Volatility. Journal Of Finance, 48(5):1749-1778.

Ewing, B. T. and Malik, F. (2013). Volatility Transmission Between Gold And Oil Futures Under Structural Breaks. International Review Of Economics And Finance, 25:113-121.

Ewing, B. T. and Malik, F. (2016). Volatility Spillovers Between Oil Prices And The Stock Market Under Structural Breaks. Global Finance Journal, 29:12-23.

Filis, G., Degiannakis, S., and Floros, C. (2011). Dynamic Correlation Between Stock Market And Oil Prices: The Case Of Oil-Importing And Oil-Exporting Countries. International Review Of Financial Analysis, 20(3):152-164.

Fisher, T. J. and Gallagher, C. M. (2012). New Weighted Portmanteau Statistics For Time Series Goodness Of Fit Testing. Journal Of The American Statistical Association, 107(498):777-787.

Fligner, M. A. and Killeen, T. J. (1976). Distribution-Free Two-Sample Tests For Scale. Journal Of The American Statistical Association, 71(353):210-213.

Ghalanos, A. (2012). rmgarch: Multivariate GARCH Models. R Package Version 0.98. Ghalanos, A. (2018). Introduction To The rugarch Package. $R$ Package Version 1.3-1.

Glosten, L. R., Jagannathan, R., and Runkle, D. E. (1993). On The Relation Between The Expected Value And The Volatility Of The Nominal Excess Return On Stocks. Journal Of Finance, 48(5):1779-1801.

Hammoudeh, S. M., Yuan, Y., McAleer, M., and Thompson, M. A. (2010). Precious Metals-Exchange Rate Volatility Transmissions And Hedging Strategies. International Review Of Economics And Finance, 19(4):633-647.

Hentschel, L. (1995). All In The Family Nesting Symmetric And Asymmetric GARCH 
Models. Journal Of Financial Economics, 39(1):71-104.

Higgins, M. L., Bera, A. K., et al. (1992). A Class Of Nonlinear ARCH Models. International Economic Review, 33(1):137-158.

Joe, H. (1997). Multivariate Models And Multivariate Dependence Concepts. Chapman And Hall/CRC.

Khalfaoui, R., Boutahar, M., and Boubaker, H. (2015). Analyzing Volatility Spillovers And Hedging Between Oil And Stock Markets: Evidence From Wavelet Analysis. Energy Economics, 49(C):540-549.

King, M. A. and Wadhwani, S. (1990). Transmission Of Volatility Between Stock Markets. Review Of Financial Studies, 3(1):5-33.

Kroner, K. F. and Ng, V. K. (1998). Modeling asymmetric comovements of asset returns. Review Of Financial Studies, 11(4):817-844.

Kroner, K. F. and Sultan, J. (1993). Time-Varying Distributions And Dynamic Hedging With Foreign Currency Futures. Journal Of Financial And Quantitative Analysis, 28(4):535-551.

Kruskal, W. H. (1958). Ordinal Measures Of Association. Journal Of The American Statistical Association, 53(284):814-861.

Levene, H. (1960). Robust Tests For Equality Of Variances. Contributions To Probability And Statistics; Essays In Honor Of Harold Hotelling, pages 278-292.

Lindskog, F., Mcneil, A., and Schmock, U. (2003). Kendall's Tau For Elliptical Distributions. In Credit Risk, pages 149-156. Springer.

Liu, M.-L., Ji, Q., and Fan, Y. (2013). How Does Oil Market Uncertainty Interact With Other Markets? An Empirical Analysis Of Implied Volatility Index. Energy, 55:860868.

Maghyereh, A. I., Awartani, B., and Tziogkidis, P. (2017). Volatility Spillovers And Cross-Hedging Between Gold, Oil And Equities: Evidence From The Gulf Cooperation Council Countries. Energy Economics, 68:440-453.

Malik, F. and Ewing, B. T. (2009). Volatility Transmission Between Oil Prices And Equity Sector Returns. International Review Of Financial Analysis, 18(3):95-100.

Malik, F. and Hammoudeh, S. (2007). Shock And Volatility Transmission In The Oil, US And Gulf Equity Markets. International Review Of Economics And Finance, 16(3):357368.

Mensi, W., Beljid, M., Boubaker, A., and Managi, S. (2013). Correlations And Volatility Spillovers Across Commodity And Stock Markets: Linking Energies, Food, And Gold. Economic Modelling, 32:15-22.

Mensi, W., Hammoudeh, S., and Yoon, S.-M. (2015). Structural Breaks, Dynamic Correlations, Asymmetric Volatility Transmission, And Hedging Strategies For Petroleum Prices And USD Exchange Rate. Energy Economics, 48:46-60.

Nelson, D. B. (1991). Conditional Heteroskedasticity In Asset Returns: A New Approach. Econometrica, 59(2):347-370.

Patton, A. J. (2006). Modelling Asymmetric Exchange Rate Dependence. International Economic Review, 47(2):527-556.

Phan, D. H. B., Sharma, S. S., and Narayan, P. K. (2016). Intraday Volatility Interaction Between The Crude Oil And Equity Markets. Journal Of International Financial Markets, Institutions And Money, 40(C):1-13. 
Sadorsky, P. (2012). Correlations And Volatility Spillovers Between Oil Prices And The Stock Prices Of Clean Energy And Rechnology Companies. Energy Economics, 34(1):248-255.

Schwert, G. W. (1990). Stock Volatility And The Crash Of'87. Review Of Financial Studies, 3(1):77-102.

Sklar, M. (1959). Fonctions De Repartition An Dimensions Et Leurs Marges. Publ. Inst. Statist. Univ. Paris, 8:229-231.

Stock, J., Elliott, G., and Rothenberg, T. (1996). Efficient Tests For An Autoregressive Unit Root. Econometrica, 64(4):813-836.

Wang, Y. and Liu, L. (2016). Crude Oil And World Stock Markets: Volatility Spillovers, Dynamic Correlations, And Hedging. Empirical Economics, 50(4):1481-1509.

Zakoian, J.-M. (1994). Threshold Heteroskedastic Models. Journal Of Economic Dynamics And Control, 18(5):931-955. 
Figure 1: Implied Volatility Indices
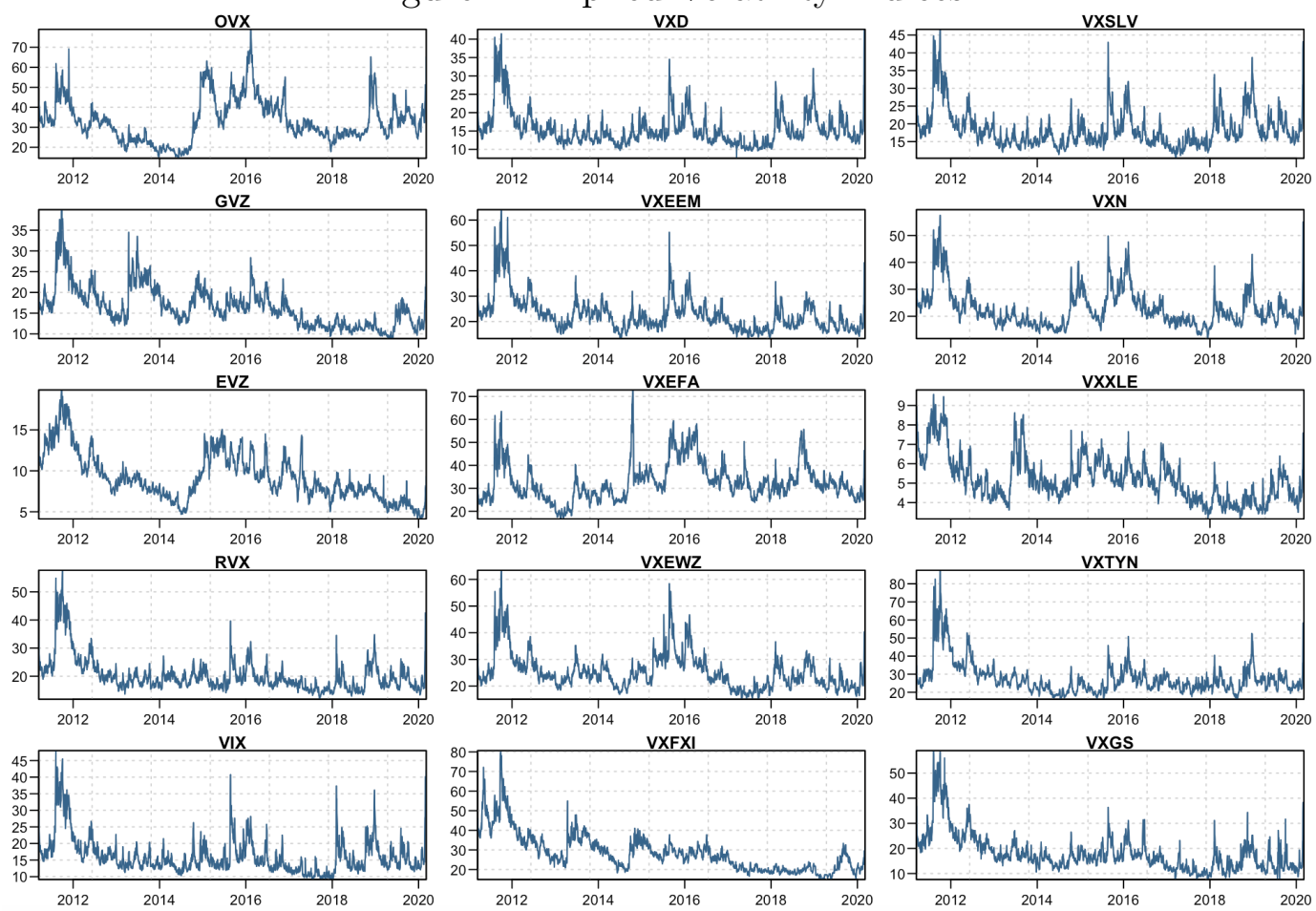

Note: $\mathrm{OVX}=\mathrm{CBOE}$ Crude Oil ETF volatility index, GVZ = Gold ETF volatility index, EVZ = Euro/dollar currency volatility index, RVX $=$ Russell 2000 volatility index, VIX $=$ S\&P 500 volatility index, VXD = CBOE DJIA Volatility Index, VXEEM = Emerging Markets ETF volatility index, VXEFA = EFA (Europe, Australia, Asia and the Far East)

ETF volatility index, VXEWZ = Brazil ETF volatility index, VXFXI = China ETF volatility index, VXSLV = Silver ETF volatility index, VXN = NASDAQ-100 volatility index, VXXLE = CBOE Energy Sector ETF volatility index, VXTYN =

CBOE 10-Year Treasury Note volatility index, VXGS = CBOE Equity VIX on Goldman Sachs volatility index.

Figure 2: Dynamic Conditional Correlations



Note: OVX $=$ CBOE Crude Oil ETF volatility index, GVZ = Gold ETF volatility index, EVZ = Euro/dollar currency volatility index, RVX $=$ Russell 2000 volatility index, VIX $=$ S\&P 500 volatility index, VXD = CBOE DJIA Volatility Index, VXEEM = Emerging Markets ETF volatility index, VXEFA = EFA (Europe, Australia, Asia and the Far East)

ETF volatility index, VXEWZ $=$ Brazil ETF volatility index, VXFXI $=$ China ETF volatility index, VXSLV $=$ Silver ETF volatility index, VXN = NASDAQ-100 volatility index, VXXLE = CBOE Energy Sector ETF volatility index, VXTYN = CBOE 10-Year Treasury Note volatility index, VXGS = CBOE Equity VIX on Goldman Sachs volatility index. 
Figure 3: Dynamic Optimal Hedge Ratios (long/short)

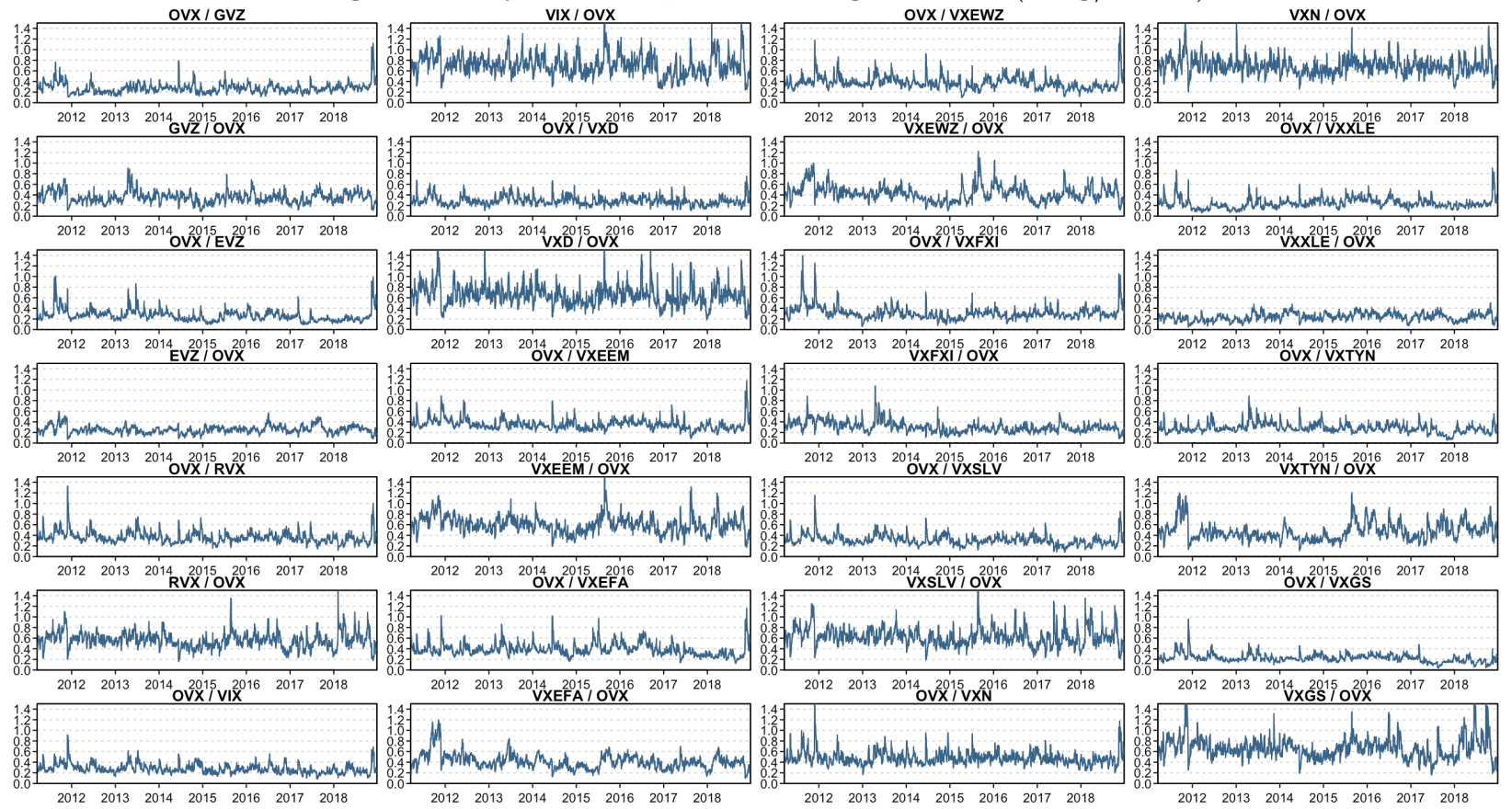

Note $:$ OVX = CBOE Crude Oil ETF volatility index, GVZ = Gold ETF volatility index, EVZ = Euro/dollar currency volatility index, RVX $=$ Russell 2000 volatility index, VIX $=$ S\&P 500 volatility index, VXD $=$ CBOE DJIA Volatility Index, VXEEM = Emerging Markets ETF volatility index, VXEFA = EFA (Europe, Australia, Asia and the Far East) ETF volatility index, VXEWZ = Brazil ETF volatility index, VXFXI = China ETF volatility index, VXSLV = Silver ETF volatility index, VXN = NASDAQ-100 volatility index, VXXLE = CBOE Energy Sector ETF volatility index, VXTYN =

CBOE 10-Year Treasury Note volatility index, VXGS = CBOE Equity VIX on Goldman Sachs volatility index.

Figure 4: Dynamic Optimal Portfolio Weights

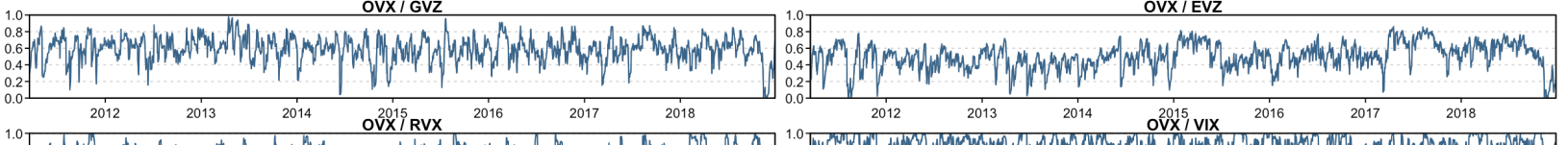

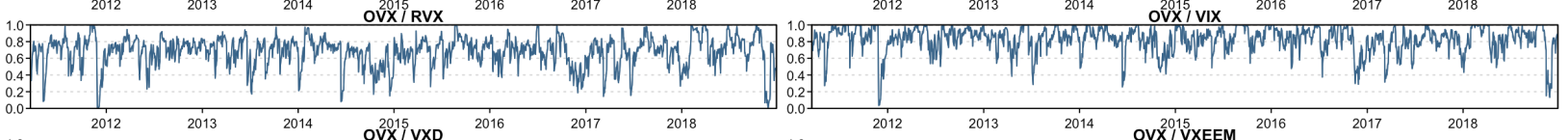

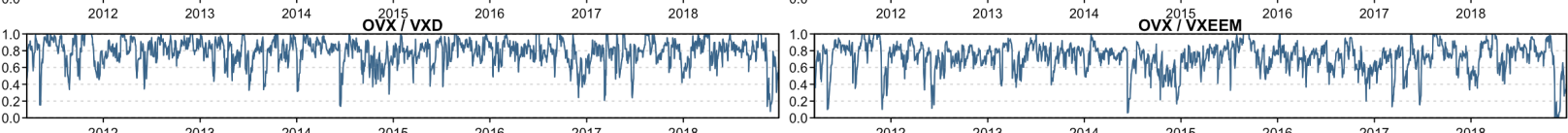

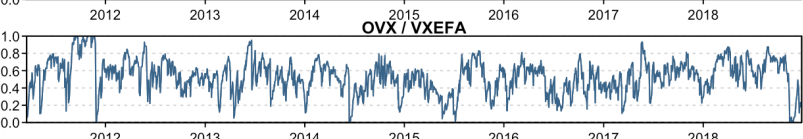

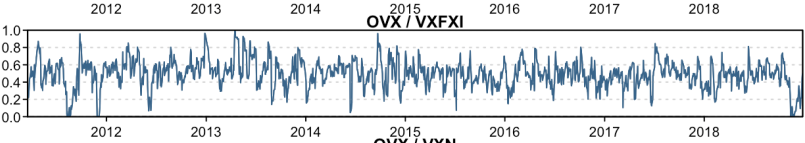

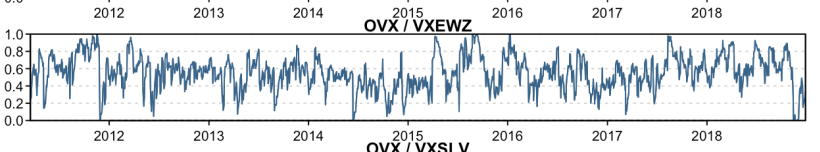



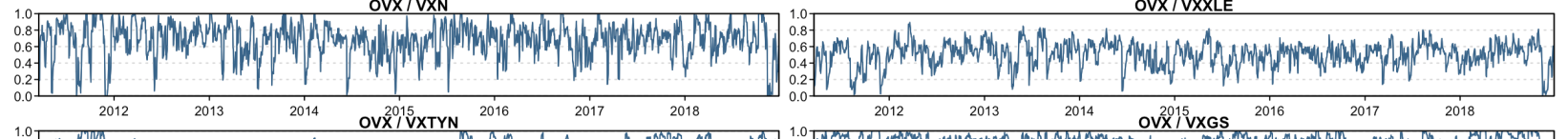

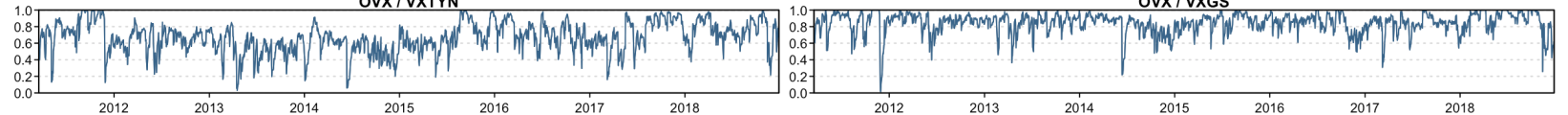

Note: OVX $=$ CBOE Crude Oil ETF volatility index, GVZ = Gold ETF volatility index, EVZ = Euro/dollar currency volatility index, RVX $=$ Russell 2000 volatility index, VIX $=$ S\&P 500 volatility index, VXD $=$ CBOE DJIA Volatility Index, VXEEM = Emerging Markets ETF volatility index, VXEFA = EFA (Europe, Australia, Asia and the Far East) ETF volatility index, VXEWZ = Brazil ETF volatility index, VXFXI $=$ China ETF volatility index, VXSLV $=$ Silver ETF volatility index, VXN = NASDAQ-100 volatility index, VXXLE = CBOE Energy Sector ETF volatility index, VXTYN =

CBOE 10-Year Treasury Note volatility index, VXGS = CBOE Equity VIX on Goldman Sachs volatility index. 
Figure 5: Cumulative Returns of the Diversification Strategies
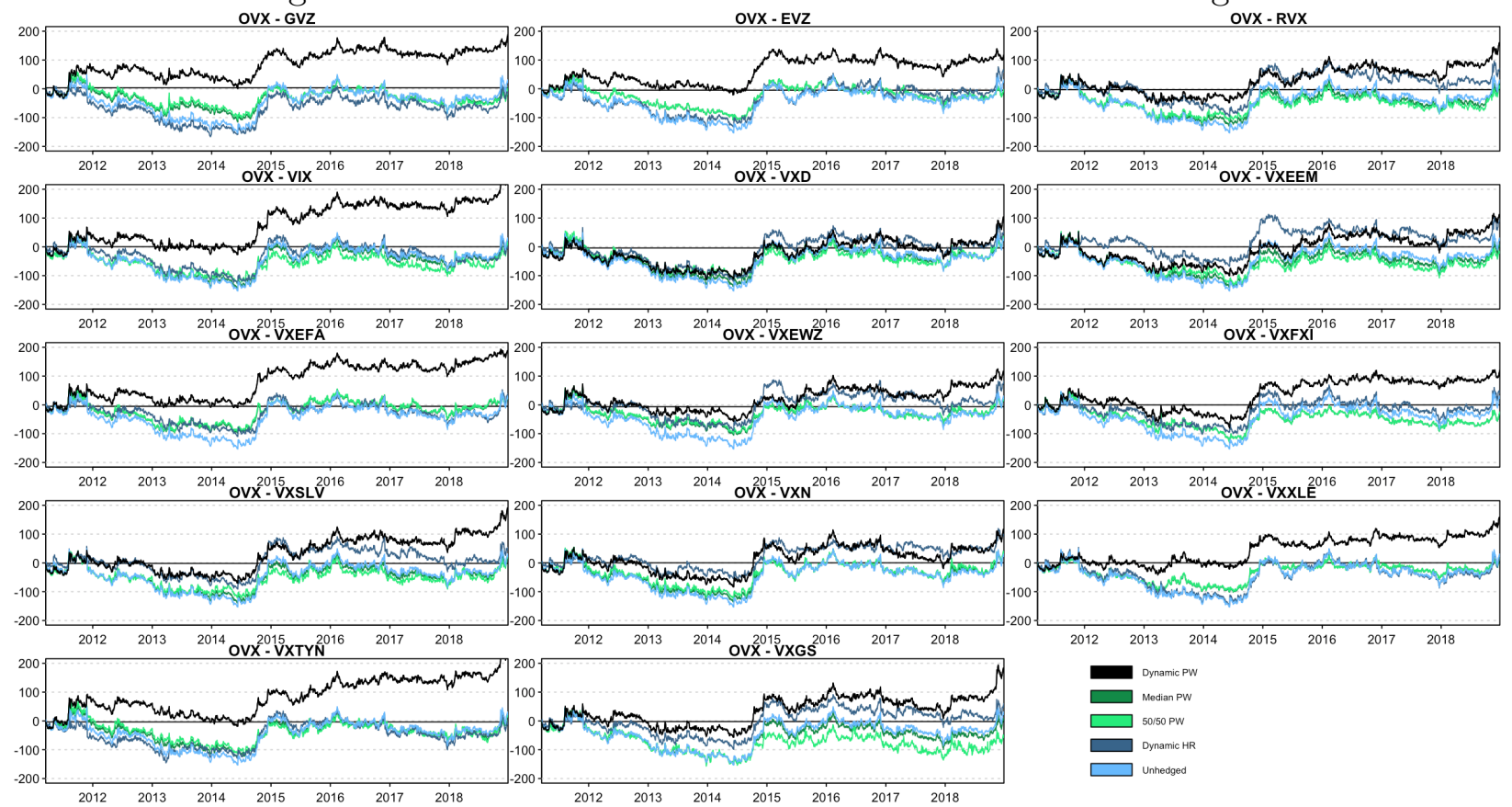

Note: The y-axis represents cumulative $\%$ returns of the different diversifications strategies. OVX $=$ CBOE Crude Oil ETF volatility index, GVZ = Gold ETF volatility index, EVZ = Euro/dollar currency volatility index, RVX = Russell 2000 volatility index, VIX = S\&P 500 volatility index, VXD = CBOE DJIA Volatility Index, VXEEM = Emerging Markets ETF volatility index, VXEFA = EFA (Europe, Australia, Asia and the Far East) ETF volatility index, VXEWZ = Brazil ETF volatility index, VXFXI $=$ China ETF volatility index, VXSLV $=$ Silver ETF volatility index, VXN $=$ NASDAQ-100 volatility index, VXXLE = CBOE Energy Sector ETF volatility index, VXTYN = CBOE 10-Year Treasury Note volatility index, VXGS = CBOE Equity VIX on Goldman Sachs volatility index.

We have cumulated the the daily profits by assuming that an investor is investing $\$ 1$ a day and take on the other day the dollar and the returns out. This strategy is not the usual one used in this literature however we overcome the problem of compound interest. Furthermore, this strategy allows us to compare the cumulative results during a specific period with each other since we only have to shift the equity line vertically. This would not be possible using an approach where you invest in the beginning and take all your investment plus profits/losses out at the end of the sample. 
Table 1: Descriptive Statistics: Implied Volatility Raw Data

\begin{tabular}{|c|c|c|c|c|c|c|c|c|}
\hline & Mean & Variance & Skewness & Kurtosis & JB & ERS & $\mathrm{LB}(20)$ & $\operatorname{LiMak}(20)$ \\
\hline OVX & 33.216 & 127.008 & $0.762 * * *$ & $0.347 * * *$ & $182.992 * * *$ & $-2.068 * *$ & $15600.671 * * *$ & $57.275 * * *$ \\
\hline GVZ & 17.588 & 22.714 & $1.237 * * *$ & $2.270 * * *$ & $845.218 * * *$ & $-3.779 * * *$ & $13971.471 * * *$ & $66.778 * * *$ \\
\hline EVZ & 9.871 & 7.84 & $0.780 * * *$ & $0.293 * *$ & $189.057 * * *$ & $-2.226 * *$ & $15693.663 * * *$ & $23.041 * * *$ \\
\hline RVX & 20.799 & 41.217 & $2.423 * * *$ & $6.917 * * *$ & $5349.661 * * *$ & $-1.620 *$ & $14718.398 * * *$ & $135.362 * * *$ \\
\hline VIX & 16.291 & 31.996 & $2.032 * * *$ & $5.111 * * *$ & $3197.765 * * *$ & $-1.780 *$ & $12416.023 * * *$ & $119.876 * * *$ \\
\hline VXD & 15.453 & 24.005 & $2.060 * * *$ & $5.134 * * *$ & $3249.973 * * *$ & $-2.012 * *$ & $12936.497 * * *$ & $121.661 * * *$ \\
\hline VXEEM & 23.449 & 52.079 & $1.909 * * *$ & $5.079 * * *$ & $3028.513 * * *$ & $-2.460 * *$ & $13128.918 * * *$ & $86.578 * * *$ \\
\hline VXEFA & 32.839 & 77.57 & $1.037 * * *$ & $1.122 * * *$ & $417.277 * * *$ & $-4.489 * * *$ & $12832.907 * * *$ & $26.896 * * *$ \\
\hline VXEWZ & 26.107 & 50.537 & $1.538 * * *$ & $3.189 * * *$ & $1472.656 * * *$ & $-2.417 * *$ & $12945.288 * * *$ & $52.752 * * *$ \\
\hline VXFXI & 30.575 & 94.09 & $1.467 * * *$ & $3.245 * * *$ & $1435.418 * * *$ & -1.521 & $14474.956 * * *$ & $18.684 * *$ \\
\hline VXSLV & 18.099 & 27.582 & $1.933 * * *$ & $4.607 * * *$ & $2713.267 * * *$ & $-1.795 *$ & $12091.974 * * *$ & $62.798 * * *$ \\
\hline VXN & 23.053 & 53.412 & $1.421 * * *$ & $2.124 * * *$ & $944.009 * * *$ & $-2.467 * *$ & $14031.705 * * *$ & $64.416 * * *$ \\
\hline VXXLE & 5.424 & 1.294 & $0.872 * * *$ & $0.527 * * *$ & $249.109 * * *$ & -0.912 & $13749.128 * * *$ & $34.276 * * *$ \\
\hline VXTYN & 28.106 & 90.314 & $2.341 * * *$ & $6.980 * * *$ & $5298.406 * * *$ & $-3.444 * * *$ & $13226.689 * * *$ & $164.610 * * *$ \\
\hline VXGS & 19.012 & 63.023 & $1.906 * * *$ & $4.655 * * *$ & $2715.148 * * *$ & -1.175 & $14588.858 * * *$ & $144.643 * * *$ \\
\hline
\end{tabular}

Note: JB=Jarque-Bera test, ERS= Stock et al. (1996) Augmented Dickey-Fuller with generalized least squares (ADF-GLS), LB(20)= Ljung-Box test for autocorrelation, LiMak(20) = Fisher and Gallagher (2012) test for ARCH effects. OVX = CBOE Crude Oil ETF volatility index, GVZ = Gold ETF volatility index, EVZ = Euro/dollar currency volatility index, RVX $=$ Russell 2000 volatility index, VIX = S\&P 500 volatility index, VXD = CBOE DJIA Volatility Index, VXEEM $=$ Emerging Markets ETF volatility index, VXEFA $=$ EFA (Europe, Australia, Asia and the Far East) ETF volatility index, VXEWZ $=$ Brazil ETF volatility index, VXFXI $=$ China ETF volatility index, VXSLV $=$ Silver ETF volatility index, VXN = NASDAQ-100 volatility index, VXXLE = CBOE Energy Sector ETF volatility index, VXTYN =

CBOE 10-Year Treasury Note volatility index, VXGS = CBOE Equity VIX on Goldman Sachs volatility index.

Table 2: Descriptive Statistics: Implied Volatility Indices Log-Returns

\begin{tabular}{|c|c|c|c|c|c|c|c|c|c|c|}
\hline & Mean & Median & Max & Min & Std.Dev. & Skewness & Kurtosis & Jarque-Bera & ERS & Obs. \\
\hline OVX & 0.010 & -0.306 & 42.497 & -43.991 & 4.923 & $0.914 * * *$ & $13.915 * * *$ & $10008.1 * * *$ & $-21.225 * * *$ & 1,961 \\
\hline GVZ & -0.017 & -0.426 & 48.073 & -30.692 & 5.413 & $0.943 * * *$ & $9.815 * * *$ & $4085.9 * * *$ & $-11.651 * * *$ & 1,961 \\
\hline EVZ & -0.026 & -0.109 & 28.910 & -39.808 & 4.615 & $-0.170 * * *$ & $8.495 * * *$ & $2476.7 * * *$ & $-19.515 * * *$ & 1,961 \\
\hline RVX & -0.008 & -0.234 & 54.045 & -36.428 & 6.018 & $0.822 * * *$ & $9.188 * * *$ & $3349.1 * * *$ & $-6.418 * * *$ & 1,961 \\
\hline VIX & -0.007 & -0.474 & 76.825 & -31.414 & 7.844 & $1.160 * * *$ & $10.604 * * *$ & $5163.9 * * *$ & $-5.808 * * *$ & 1,961 \\
\hline VXD & -0.001 & -0.374 & 35.114 & -40.810 & 7.131 & $0.550 * * *$ & $6.929 * * *$ & $1360.6 * * *$ & $-5.439 * * *$ & 1,961 \\
\hline VXEEM & -0.014 & -0.553 & 50.486 & -29.807 & 6.219 & $0.879 * * *$ & 7.633 *** & $2006.4 * * *$ & $-6.199 * * *$ & 1,961 \\
\hline VXEFA & 0.007 & -0.220 & 32.396 & -61.958 & 5.020 & $-0.364 * * *$ & $17.997 * * *$ & $18419.4 * * *$ & $-9.829 * * *$ & 1,961 \\
\hline VXEWZ & -0.015 & -0.411 & 36.577 & -20.281 & 5.164 & $0.872 * * *$ & $6.934 * * *$ & $1513.3 * * *$ & $-3.600 * * *$ & 1,961 \\
\hline VXFXI & -0.038 & -0.447 & 56.610 & -25.126 & 4.761 & $1.751 * * *$ & $17.262 * * *$ & $17622.7 * * *$ & $-12.207 * * *$ & 1,961 \\
\hline VXSLV & 0.001 & -0.552 & 46.891 & -25.615 & 6.710 & $0.852 * * *$ & 6.801 *** & 1417.8 *** & $-6.916 * * *$ & 1,961 \\
\hline VXN & 0.001 & -0.354 & 29.808 & -31.032 & 5.627 & $0.494 * * *$ & $5.630 * * *$ & $644.9 * * *$ & $-5.312 * * *$ & 1,961 \\
\hline VXXLE & -0.034 & -0.180 & 28.768 & -23.979 & 4.632 & $0.246 * * *$ & $5.714 * * *$ & $621.5 * * *$ & $-10.145 * * *$ & 1,961 \\
\hline VXTYN & 0.008 & -0.352 & 44.377 & -29.290 & 6.423 & $0.705 * * *$ & 7.723 *** & $1985.6 * * *$ & $-4.503 * * *$ & 1,961 \\
\hline VXGS & -0.033 & -0.407 & 55.651 & -68.669 & 8.681 & -0.064 & $11.060 * * *$ & $5308.8 * * *$ & $-4.205 * * *$ & 1,961 \\
\hline
\end{tabular}

Note: JB=Jarque-Bera test, ERS= Stock et al. (1996) Augmented Dickey-Fuller with generalized least squares

(ADF-GLS), LB(20)= Ljung-Box test for autocorrelation, LiMak(20) = Fisher and Gallagher (2012) test for ARCH effects. OVX $=$ CBOE Crude Oil ETF volatility index, GVZ = Gold ETF volatility index, EVZ = Euro/dollar currency volatility index, RVX $=$ Russell 2000 volatility index, VIX $=$ S\&P 500 volatility index, VXD = CBOE DJIA Volatility Index, VXEEM $=$ Emerging Markets ETF volatility index, VXEFA = EFA (Europe, Australia, Asia and the Far East) ETF volatility index, VXEWZ = Brazil ETF volatility index, VXFXI $=$ China ETF volatility index, VXSLV $=$ Silver ETF volatility index, VXN = NASDAQ-100 volatility index, VXXLE = CBOE Energy Sector ETF volatility index, VXTYN = CBOE 10-Year Treasury Note volatility index, VXGS = CBOE Equity VIX on Goldman Sachs volatility index. 
Table 3: Monte Carlo Simulation: Power of Variance Tests

\begin{tabular}{|c|c|c|c|c|c|c|c|c|c|c|c|c|}
\hline & \multicolumn{3}{|c|}{ F-Test } & \multicolumn{3}{|c|}{ Levene Test } & \multicolumn{3}{|c|}{ Brown \& Forsyth Test } & \multicolumn{3}{|c|}{ Fligner-Killeen Test } \\
\hline & $10 \%$ & $5 \%$ & $1 \%$ & $10 \%$ & $5 \%$ & $1 \%$ & $10 \%$ & $5 \%$ & $1 \%$ & $10 \%$ & $5 \%$ & $1 \%$ \\
\hline $\mathrm{N}(0,1)$ & 10.3 & 4.9 & 0.9 & 10.3 & 5.0 & 1.0 & 9.9 & 4.7 & 0.9 & 9.5 & 4.4 & 0.9 \\
\hline $\mathrm{t}(3)$ & 52.2 & 45.2 & 32.8 & 9.9 & 5.0 & 0.9 & 9.7 & 4.9 & 0.8 & 10.1 & 5.3 & 0.9 \\
\hline $\operatorname{GED}(0,1)$ & 29.2 & 20.7 & 9.3 & 9.9 & 4.7 & 1.0 & 9.6 & 4.5 & 0.9 & 9.7 & 4.4 & 0.8 \\
\hline Skewed $\mathrm{N}(0,1,2)$ & 14.4 & 7.9 & 2.2 & 12.6 & 6.7 & 1.7 & 10.2 & 5.0 & 1.2 & 11.2 & 5.5 & 1.2 \\
\hline Skewed $\mathrm{t}(3,2)$ & 59.2 & 52.3 & 40.4 & 13.0 & 6.6 & 1.6 & 9.6 & 4.1 & 0.7 & 12.1 & 6.6 & 1.7 \\
\hline Skewed $\operatorname{GED}(0,1,2)$ & 37.7 & 28.7 & 16.3 & 15.5 & 8.3 & 2.4 & 9.7 & 4.8 & 0.8 & 13.7 & 7.7 & 2.0 \\
\hline $\mathrm{N}(0,1)$ with Outlier & 99.9 & 99.8 & 98.8 & 7.2 & 2.3 & 0.1 & 7.1 & 2.2 & 0.1 & 9.6 & 4.5 & 1.0 \\
\hline $\mathrm{t}(3)$ with Outlier & 97.7 & 97.1 & 95.6 & 3.1 & 0.5 & 0.0 & 3.1 & 0.5 & 0.0 & 8.9 & 4.5 & 0.7 \\
\hline $\operatorname{GED}(0,1)$ with Outlier & 99.7 & 98.6 & 92.4 & 7.9 & 3.2 & 0.2 & 7.7 & 3.0 & 0.2 & 9.4 & 4.5 & 0.8 \\
\hline
\end{tabular}

Note: For each scenario, we repeated the statistics estimation process 50,000 times based upon simulated time series with 1,000 observations (each series in the dataset consists of 1,961 observations).

Table 4: Dynamic Conditional Correlations

\begin{tabular}{lcc}
\hline \hline$\tau_{i j t}$ & Coefficient & Std. Error \\
\hline OVX-GVZ & $0.301 * * *$ & {$[0.002]$} \\
OVX-EVZ & $0.252 * * *$ & {$[0.001]$} \\
OVX-RVX & $0.444 * * *$ & {$[0.002]$} \\
OVX-VIX & $0.425 * * *$ & {$[0.002]$} \\
OVX-VXD & $0.420 * * *$ & {$[0.002]$} \\
OVX-VXEEM & $0.449 * * *$ & {$[0.002]$} \\
OVX-VXEFA & $0.400 * * *$ & {$[0.002]$} \\
OVX-VXEWZ & $0.389 * * *$ & {$[0.002]$} \\
OVX-VXFXI & $0.310 * * *$ & {$[0.002]$} \\
OVX-VXSLV & $0.436 * * *$ & {$[0.002]$} \\
OVX-VXN & $0.555 * * *$ & {$[0.001]$} \\
OVX-VXXLE & $0.233 * * *$ & {$[0.002]$} \\
OVX-VXTYN & $0.351 * * *$ & {$[0.002]$} \\
OVX-VXGS & $0.400 * * *$ & {$[0.002]$} \\
$\alpha$ & $0.013 * * *$ & {$[0.001]$} \\
$\beta$ & $0.972 * * *$ & {$[0.005]$} \\
df & $21.575 * * *$ & {$[1.864]$} \\
\hline
\end{tabular}

Note: $\rho_{i j t}$ denotes the time-varying conditional correlation. $* * *$ denotes significance at $1 \%$ level. OVX $=$ CBOE Crude Oil ETF volatility index, GVZ = Gold ETF volatility index, EVZ = Euro/dollar currency volatility index, RVX $=$ Russell 2000 volatility index, VIX $=$ S\&P 500 volatility index, VXD = CBOE DJIA Volatility Index, VXEEM = Emerging Markets ETF volatility index, VXEFA = EFA (Europe, Australia, Asia and the Far East) ETF volatility index, VXEWZ $=$ Brazil ETF volatility index, VXFXI = China ETF volatility index, VXSLV = Silver ETF volatility index, VXN = NASDAQ-100 volatility index, VXXLE = CBOE Energy Sector ETF volatility index, VXTYN = CBOE 10-Year Treasury Note volatility index, VXGS = CBOE Equity VIX on Goldman Sachs volatility index. 
Table 5: Dynamic Optimal Hedge Ratios

\begin{tabular}{lcccc}
\hline \hline$\beta_{j i t}$ & Median & Std.Dev. & $5 \%$ & $95 \%$ \\
\hline OVX/GVZ & 0.260 & 0.100 & 0.160 & 0.430 \\
OVX/EVZ & 0.250 & 0.110 & 0.140 & 0.460 \\
OVX/RVX & 0.340 & 0.110 & 0.230 & 0.550 \\
OVX/VIX & 0.260 & 0.090 & 0.170 & 0.440 \\
OVX/VXD & 0.270 & 0.080 & 0.180 & 0.440 \\
OVX/VXEEM & 0.340 & 0.110 & 0.230 & 0.530 \\
OVX/VXEFA & 0.370 & 0.120 & 0.230 & 0.630 \\
OVX/VXEWZ & 0.360 & 0.120 & 0.220 & 0.580 \\
OVX/VXFXI & 0.290 & 0.120 & 0.170 & 0.500 \\
OVX/VXSLV & 0.290 & 0.100 & 0.180 & 0.480 \\
OVX/VXN & 0.460 & 0.130 & 0.320 & 0.690 \\
OVX/VXXLE & 0.230 & 0.100 & 0.120 & 0.410 \\
OVX/VXTYN & 0.270 & 0.090 & 0.160 & 0.450 \\
OVX/VXGS & 0.210 & 0.080 & 0.120 & 0.360 \\
GVZ/OVX & 0.350 & 0.110 & 0.200 & 0.540 \\
EVZ/OVX & 0.250 & 0.070 & 0.140 & 0.390 \\
RVX/OVX & 0.560 & 0.150 & 0.330 & 0.820 \\
VIX/OVX & 0.690 & 0.200 & 0.390 & 1.070 \\
VXD/OVX & 0.630 & 0.200 & 0.360 & 0.990 \\
VXEEM/OVX & 0.600 & 0.170 & 0.360 & 0.870 \\
VXEFA/OVX & 0.400 & 0.150 & 0.230 & 0.630 \\
VXEWZ/OVX & 0.420 & 0.150 & 0.220 & 0.730 \\
VXFXI/OVX & 0.290 & 0.100 & 0.170 & 0.490 \\
VXSLV/OVX & 0.610 & 0.180 & 0.370 & 0.930 \\
VXN/OVX & 0.670 & 0.160 & 0.450 & 0.950 \\
VXXLE/OVX & 0.240 & 0.070 & 0.120 & 0.370 \\
VXTYN/OVX & 0.440 & 0.170 & 0.260 & 0.810 \\
VXGS/OVX & 0.650 & 0.200 & 0.380 & 0.990 \\
\hline
\end{tabular}

Note: $\beta_{j i t}$ refers to the optimal hedge ratio for a long position in implied volatility index $i$ and a short position in $j$. OVX $=\mathrm{CBOE}$ Crude Oil ETF volatility index, GVZ = Gold ETF volatility index, EVZ = Euro/dollar currency volatility index, RVX $=$ Russell 2000 volatility index, VIX $=$ S\&P 500 volatility index, VXD = CBOE DJIA Volatility Index, VXEEM $=$ Emerging Markets ETF volatility index, VXEFA = EFA (Europe, Australia, Asia and the Far East) ETF volatility index, VXEWZ $=$ Brazil ETF volatility index, VXFXI $=$ China ETF volatility index, VXSLV $=$ Silver ETF volatility index, VXN $=$ NASDAQ-100 volatility index, VXXLE $=$ CBOE Energy Sector ETF volatility index, VXTYN $=$ CBOE 10-Year Treasury Note volatility index, VXGS = CBOE Equity VIX on Goldman Sachs volatility index. 
Table 6: Dynamic Optimal Portfolio Weights

\begin{tabular}{lcccc}
\hline \hline$w_{j i t}$ & Median & Std.Dev. & $5 \%$ & $95 \%$ \\
\hline OVX/GVZ & 0.600 & 0.150 & 0.320 & 0.810 \\
OVX/EVZ & 0.510 & 0.160 & 0.210 & 0.740 \\
OVX/RVX & 0.720 & 0.180 & 0.340 & 0.930 \\
OVX/VIX & 0.860 & 0.160 & 0.520 & 1.000 \\
OVX/VXD & 0.810 & 0.160 & 0.480 & 1.000 \\
OVX/VXEEM & 0.750 & 0.170 & 0.390 & 0.950 \\
OVX/VXEFA & 0.550 & 0.190 & 0.190 & 0.820 \\
OVX/VXEWZ & 0.560 & 0.190 & 0.220 & 0.870 \\
OVX/VXFXI & 0.500 & 0.160 & 0.220 & 0.760 \\
OVX/VXSLV & 0.790 & 0.170 & 0.440 & 0.980 \\
OVX/VXN & 0.710 & 0.210 & 0.290 & 0.980 \\
OVX/VXXLE & 0.520 & 0.150 & 0.220 & 0.720 \\
OVX/VXTYN & 0.670 & 0.180 & 0.340 & 0.950 \\
OVX/VXGS & 0.870 & 0.130 & 0.600 & 1.000 \\
\hline
\end{tabular}

Note: $w_{j i t}$ refers to the optimal portfolio weight in the OVX. OVX $=$ CBOE Crude Oil ETF volatility index, GVZ $=$ Gold ETF volatility index, EVZ = Euro/dollar currency volatility index, RVX = Russell 2000 volatility index, VIX $=$ S\&P 500 volatility index, $\mathrm{VXD}=\mathrm{CBOE}$ DJIA Volatility Index, VXEEM = Emerging Markets ETF volatility index, VXEFA $=$ EFA (Europe, Australia, Asia and the Far East) ETF volatility index, VXEWZ = Brazil ETF volatility index, VXFXI = China ETF volatility index, VXSLV $=$ Silver ETF volatility index, VXN $=$ NASDAQ-100 volatility index, VXXLE $=$ CBOE Energy Sector ETF volatility index, VXTYN = CBOE 10-Year Treasury Note volatility index, VXGS = CBOE Equity VIX on Goldman Sachs volatility index.

Table 7: Hedging Effectiveness of the Diversification Strategies

\begin{tabular}{lcccc}
\hline & \multicolumn{2}{c}{ Dynamic Portfolio Weights } & \multicolumn{2}{c}{ Dynamic } \\
& HE & p-value & HE & p-value \\
\hline OVX/GVZ & $0.094 *$ & 0.064 & $0.445 * * *$ & 0.000 \\
OVX/EVZ & 0.049 & 0.359 & $0.387 * * *$ & 0.000 \\
OVX/RVX & $0.18 * * *$ & 0.000 & $0.472 * * *$ & 0.000 \\
OVX/VIX & $0.194 * * *$ & 0.001 & $0.649 * * *$ & 0.000 \\
OVX/VXD & $0.152 * * *$ & 0.002 & $0.569 * * *$ & 0.000 \\
OVX/VXEEM & $0.247 * * *$ & 0.000 & $0.469 * * *$ & 0.000 \\
OVX/VXEFA & $0.160 * * *$ & 0.005 & $0.345 * * *$ & 0.000 \\
OVX/VXEWZ & $0.184 * * *$ & 0.002 & $0.370 * * *$ & 0.000 \\
OVX/VXFXI & 0.127 & 0.145 & $0.377 * * *$ & 0.000 \\
OVX/VXSLV & $0.176 * * *$ & 0.002 & $0.543 * * *$ & 0.000 \\
OVX/VXN & $0.325 * * *$ & 0.000 & $0.345 * * *$ & 0.000 \\
OVX/VXXLE & 0.052 & 0.224 & $0.400 * * *$ & 0.000 \\
OVX/VXTYN & $0.108 * *$ & 0.024 & $0.520 * * *$ & 0.000 \\
OVX/VXGS & $0.139 * * *$ & 0.009 & $0.684 * * *$ & 0.000 \\
\hline
\end{tabular}

Note: HE denotes hedging effectiveness. $* * *, * * *$ denote significance at $1 \%, 5 \%$ and $10 \%$ level, respectively. OVX $=$ CBOE Crude Oil ETF volatility index, GVZ = Gold ETF volatility index, EVZ = Euro/dollar currency volatility index, RVX $=$ Russell 2000 volatility index, VIX $=$ S\&P 500 volatility index, VXD = CBOE DJIA Volatility Index, VXEEM = Emerging Markets ETF volatility index, VXEFA = EFA (Europe, Australia, Asia and the Far East) ETF volatility index,

$\mathrm{VXEWZ}=$ Brazil ETF volatility index, VXFXI $=$ China ETF volatility index, VXSLV $=$ Silver ETF volatility index, VXN $=$ NASDAQ-100 volatility index, VXXLE $=$ CBOE Energy Sector ETF volatility index, VXTYN $=$ CBOE 10-Year Treasury Note volatility index, VXGS = CBOE Equity VIX on Goldman Sachs volatility index. 
Table 8: Cumulative Returns of the Diversification Strategies

\begin{tabular}{lccccc}
\hline & \multicolumn{2}{c}{ Portfolio weights strategy } & Hedge Ratios & $\begin{array}{c}\text { Buy and Hold } \\
\text { Unhedged }\end{array}$ \\
\hline Dynamic & Median & $50 / 50$ & Dynamic & 22.13 \\
EVZ & 182.22 & -0.61 & -6.37 & -18.67 & 22.13 \\
RVX & 115.70 & -7.70 & -8.03 & 56.98 & 22.13 \\
VIX & 151.91 & 10.73 & 2.11 & 65.13 & 22.13 \\
VXD & 250.68 & 17.67 & 6.00 & -4.31 & 22.13 \\
VXEEM & 96.68 & 24.83 & 29.28 & 45.71 & 22.13 \\
VXEFA & 104.17 & 0.28 & -21.71 & 87.79 & 22.13 \\
VXEWZ & 187.24 & 21.62 & 21.57 & 29.33 & 22.13 \\
VXFXI & 107.88 & 15.23 & 14.35 & 74.31 & 22.13 \\
VXSLV & 115.14 & -29.96 & -29.87 & 41.22 & 22.13 \\
VXN & 185.52 & 20.03 & 17.10 & 45.13 & 22.13 \\
VXXLE & 153.22 & 27.35 & 31.09 & 95.87 & 22.13 \\
VXTYN & 247.14 & 12.75 & 12.31 & 9.64 & 22.13 \\
VXGS & 180.82 & 2.96 & -50.72 & 46.95 & 22.13 \\
Average & 156.10 & 9.54 & 2.40 & 40.28 & 22.13 \\
\hline
\end{tabular}

Note: The buy and hold unhedged strategy refers to the OVX only. OVX $=$ CBOE Crude Oil ETF volatility index, GVZ $=$ Gold ETF volatility index, EVZ = Euro/dollar currency volatility index, RVX $=$ Russell 2000 volatility index, VIX = S\&P 500 volatility index, VXD = CBOE DJIA Volatility Index, VXEEM = Emerging Markets ETF volatility index, VXEFA = EFA (Europe, Australia, Asia and the Far East) ETF volatility index, VXEWZ = Brazil ETF volatility index,

VXFXI = China ETF volatility index, VXSLV = Silver ETF volatility index, VXN = NASDAQ-100 volatility index, VXXLE = CBOE Energy Sector ETF volatility index, VXTYN = CBOE 10-Year Treasury Note volatility index, VXGS = CBOE Equity VIX on Goldman Sachs volatility index. 


\section{A Online Appendix}

Table A.1: DCC-GARCH t-Copula results

\begin{tabular}{|c|c|c|c|c|c|c|c|c|c|c|c|c|c|c|c|}
\hline & OVX & GVZ & EVZ & RVX & VIX & VXD & VXEEM & VXEFA & VXEWZ & VXFXI & VXSLV & VXN & VXXLE & VXTYN & VXGS \\
\hline & GJRGARCF & צJRGARC & GJRGARC & GJRGARCH & GJRGARCI & TGARCH & GJRGARCF & TGARCH & JRGARCI & TGARCH & JRGARC & JRGAR & TGARCH & GJRARCH & GJRARCH \\
\hline & SSTD & SSTD & SSTD & SSTD & SGED & SSTD & SSTD & SSTD & SSTD & SSTD & SSTD & SSTD & STD & SSTD & SSTD \\
\hline \multirow[t]{2}{*}{$\mu$} & 0.038 & 0.047 & 0.049 & 0.125 & 0.259 & 0.100 & 0.197 & 0.166 & 0.063 & 0.085 & 0.177 & 0.136 & 0.018 & 0.139 & 0.242 \\
\hline & {$[0.105]$} & [0.124] & {$[0.103]$} & {$[0.133]$} & {$[0.258]$} & {$[0.162]$} & {$[0.137]$} & {$[0.110]$} & {$[0.106]$} & {$[0.107]$} & {$[0.150]$} & {$[0.128]$} & {$[0.103]$} & [0.129] & {$[0.177]$} \\
\hline$\omega$ & $\begin{array}{c}3.717 \\
{[2.712]}\end{array}$ & $\begin{array}{c}6.004 * * \\
{[3.011]}\end{array}$ & $\begin{array}{c}0.403 * * \\
{[0.172]}\end{array}$ & $\begin{array}{c}3.181 * * * \\
{[0.780]}\end{array}$ & $\begin{array}{c}6.659 * * * \\
{[1.461]}\end{array}$ & $\begin{array}{c}0.474 * * * \\
{[0.183]}\end{array}$ & $\begin{array}{c}3.857 * * * \\
{[0.776]}\end{array}$ & $\begin{array}{l}0.114 * \\
{[0.064]}\end{array}$ & $\begin{array}{c}1.917 * * * \\
{[0.652]}\end{array}$ & $\begin{array}{c}0.453 * * \\
{[0.197]}\end{array}$ & $\begin{array}{c}5.262 * * * \\
{[1.261]}\end{array}$ & $\begin{array}{c}4.658 * * * \\
{[1.109]}\end{array}$ & $\begin{array}{l}0.813 * \\
{[0.429]}\end{array}$ & $\begin{array}{c}1.290 * * \\
{[0.599]}\end{array}$ & $\begin{array}{c}9.612 * * * \\
{[3.398]}\end{array}$ \\
\hline$\alpha$ & $\begin{array}{l}0.095 * \\
{[0.055]}\end{array}$ & $\begin{array}{c}0.096 * * \\
{[0.043]}\end{array}$ & $\begin{array}{c}0.035 * * * \\
{[0.010]}\end{array}$ & $\begin{array}{c}0.039 * * * \\
{[0.008]}\end{array}$ & $\begin{array}{c}0.071 * * * \\
{[0.015]}\end{array}$ & $\begin{array}{c}0.098 * * * \\
{[0.037]}\end{array}$ & $\begin{array}{c}0.046 * * * \\
{[0.008]}\end{array}$ & $\begin{array}{c}0.064 * * * \\
{[0.022]}\end{array}$ & $\begin{array}{c}0.094 * * * \\
{[0.028]}\end{array}$ & $\begin{array}{c}0.097 * * * \\
{[0.033]}\end{array}$ & $\begin{array}{l}0.080 * \\
{[0.043]}\end{array}$ & $\begin{array}{c}0.110 * * * \\
{[0.038]}\end{array}$ & $\begin{array}{l}0.079 * \\
{[0.042]}\end{array}$ & $\begin{array}{c}0.036 * * * \\
{[0.010]}\end{array}$ & $\begin{array}{c}0.059 * * * \\
{[0.015]}\end{array}$ \\
\hline$\beta$ & $\begin{array}{c}0.727 * * * \\
{[0.162]}\end{array}$ & $\begin{array}{c}0.697 * * * \\
{[0.129]}\end{array}$ & $\begin{array}{c}0.946 * * * \\
{[0.015]}\end{array}$ & $\begin{array}{c}0.831 * * * \\
{[0.030]}\end{array}$ & $\begin{array}{c}0.762 * * * \\
{[0.035]}\end{array}$ & $\begin{array}{c}0.863 * * * \\
{[0.051]}\end{array}$ & $\begin{array}{c}0.814 * * * \\
{[0.027]}\end{array}$ & $\begin{array}{c}0.933 * * * \\
{[0.027]}\end{array}$ & $\begin{array}{c}0.821 * * * \\
{[0.045]}\end{array}$ & $\begin{array}{c}0.838 * * * \\
{[0.061]}\end{array}$ & $\begin{array}{c}0.778 * * * \\
{[0.041]}\end{array}$ & $\begin{array}{c}0.737 * * * \\
{[0.055]}\end{array}$ & $\begin{array}{c}0.769 * * * \\
{[0.118]}\end{array}$ & $\begin{array}{c}0.901 * * * \\
{[0.030]}\end{array}$ & $\begin{array}{c}0.739 * * * \\
{[0.073]}\end{array}$ \\
\hline$\gamma$ & $\begin{array}{c}-0.483 * * \\
{[0.206]}\end{array}$ & $\begin{array}{c}-0.404 * * * \\
{[0.157]}\end{array}$ & $\begin{array}{c}-0.347 * * * \\
{[0.122]}\end{array}$ & $\begin{array}{c}-1.000 * * * \\
{[0.000]}\end{array}$ & $\begin{array}{c}-1.000 * * * \\
{[0.009]}\end{array}$ & $\begin{array}{c}-1.000 * * \\
{[0.450]}\end{array}$ & $\begin{array}{c}-0.999 * * * \\
{[0.001]}\end{array}$ & $\begin{array}{c}-0.827 * * * \\
{[0.261]}\end{array}$ & $\begin{array}{c}-0.354 * * * \\
{[0.126]}\end{array}$ & $\begin{array}{c}-0.830 * * * \\
{[0.273]}\end{array}$ & $\begin{array}{c}-0.685 * \\
{[0.390]}\end{array}$ & $\begin{array}{c}-0.377 * * \\
{[0.181]}\end{array}$ & $\begin{array}{c}-0.898 * \\
{[0.485]}\end{array}$ & $\begin{array}{c}-0.999 * * * \\
{[0.004]}\end{array}$ & $\begin{array}{c}-1.000 * * * \\
{[0.003]}\end{array}$ \\
\hline Skewness & $\begin{array}{c}1.165 * * * \\
{[0.040]}\end{array}$ & $\begin{array}{c}1.259 * * * \\
{[0.042]}\end{array}$ & $\begin{array}{c}1.066 * * * \\
{[0.035]}\end{array}$ & $\begin{array}{c}1.182 * * * \\
{[0.043]}\end{array}$ & $\begin{array}{c}1.201 * * * \\
{[0.059]}\end{array}$ & $\begin{array}{c}1.232 * * * \\
{[0.047]}\end{array}$ & $\begin{array}{c}1.285 * * * \\
{[0.045]}\end{array}$ & $\begin{array}{c}1.208 * * * \\
{[0.043]}\end{array}$ & $\begin{array}{c}1.307 * * * \\
{[0.048]}\end{array}$ & $\begin{array}{c}1.301 * * * \\
{[0.042]}\end{array}$ & $\begin{array}{c}1.229 * * * \\
{[0.042]}\end{array}$ & $\begin{array}{c}1.196 * * * \\
{[0.042]}\end{array}$ & & $\begin{array}{c}1.142 * * * \\
{[0.034]}\end{array}$ & $\begin{array}{c}1.185 * * * \\
{[0.039]}\end{array}$ \\
\hline \multirow[t]{2}{*}{ Shape } & $\begin{array}{c}5.058 * * * \\
{[0.620]}\end{array}$ & $\begin{array}{c}5.046 * * * \\
{[0.603]}\end{array}$ & $\begin{array}{c}4.397 * * * \\
{[0.463]}\end{array}$ & $\begin{array}{c}6.518 * * * \\
{[0.916]}\end{array}$ & $\begin{array}{c}1.197 * * * \\
{[0.060]}\end{array}$ & $\begin{array}{c}4.968 * * * \\
{[0.591]}\end{array}$ & $\begin{array}{c}6.085 * * * \\
{[0.882]}\end{array}$ & $\begin{array}{c}4.649 * * * \\
{[0.519]}\end{array}$ & $\begin{array}{c}5.459 * * * \\
{[0.651]}\end{array}$ & $\begin{array}{c}5.091 * * * \\
{[0.626]}\end{array}$ & $\begin{array}{c}5.284 * * * \\
{[0.628]}\end{array}$ & $\begin{array}{c}6.788 * * * \\
{[1.020]}\end{array}$ & $\begin{array}{c}5.933 * * * \\
{[0.740]}\end{array}$ & $\begin{array}{c}4.298 * * * \\
{[0.440]}\end{array}$ & $\begin{array}{c}5.178 * * * \\
{[0.645]}\end{array}$ \\
\hline & \multicolumn{15}{|c|}{ Misspecification Statistics } \\
\hline Sign Bias & $\begin{array}{c}1.052 \\
(0.293)\end{array}$ & $\begin{array}{l}1.405 \\
(0.160)\end{array}$ & $\begin{array}{c}0.251 \\
(0.802)\end{array}$ & $\begin{array}{l}1.006 \\
(0.315)\end{array}$ & $\begin{array}{c}1.071 \\
(0.284)\end{array}$ & $\begin{array}{c}0.134 \\
(0.893)\end{array}$ & $\begin{array}{c}0.309 \\
(0.757)\end{array}$ & $\begin{array}{c}0.247 \\
(0.805)\end{array}$ & $\begin{array}{c}0.011 \\
(0.991)\end{array}$ & $\begin{array}{c}0.350 \\
(0.726)\end{array}$ & $\begin{array}{c}0.261 \\
(0.794)\end{array}$ & $\begin{array}{c}0.308 \\
(0.758)\end{array}$ & $\begin{array}{c}0.973 \\
(0.331)\end{array}$ & $\begin{array}{c}0.384 \\
(0.701)\end{array}$ & $\begin{array}{c}0.235 \\
(0.815)\end{array}$ \\
\hline $\operatorname{LiMak}(20)$ & $\begin{array}{c}4.003 \\
(0.983)\end{array}$ & $\begin{array}{l}7.417 \\
(0.770)\end{array}$ & $\begin{array}{c}5.975 \\
(0.894)\end{array}$ & $\begin{array}{c}6.711 \\
(0.836)\end{array}$ & $\begin{array}{c}6.774 \\
(0.831)\end{array}$ & $\begin{array}{l}14.658 \\
(0.130)\end{array}$ & $\begin{array}{l}13.335 \\
(0.200)\end{array}$ & $\begin{array}{c}3.194 \\
(0.995)\end{array}$ & $\begin{array}{l}8.389 \\
(0.667)\end{array}$ & $\begin{array}{c}7.048 \\
(0.806)\end{array}$ & $\begin{array}{c}10.962 \\
(0.390)\end{array}$ & $\begin{array}{c}5.761 \\
(0.909)\end{array}$ & $\begin{array}{l}5.341 \\
(0.933)\end{array}$ & $\begin{array}{l}10.377 \\
(0.449)\end{array}$ & $\begin{array}{l}7.647 \\
(0.746)\end{array}$ \\
\hline VaR & $\begin{array}{l}0.055 \\
(0.815)\end{array}$ & $\begin{array}{c}0.000 \\
(0.996)\end{array}$ & $\begin{array}{c}1.842 \\
(0.175)\end{array}$ & $\begin{array}{l}1.842 \\
(0.175)\end{array}$ & $\begin{array}{l}1.301 \\
(0.254)\end{array}$ & $\begin{array}{c}0.055 \\
(0.815)\end{array}$ & $\begin{array}{c}1.301 \\
(0.254)\end{array}$ & $\begin{array}{c}0.486 \\
(0.486)\end{array}$ & $\begin{array}{l}0.057 \\
(0.811)\end{array}$ & $\begin{array}{c}0.229 \\
(0.632)\end{array}$ & $\begin{array}{c}1.842 \\
(0.175)\end{array}$ & $\begin{array}{l}0.848 \\
(0.357)\end{array}$ & $\begin{array}{l}0.529 \\
(0.467)\end{array}$ & $\begin{array}{l}1.842 \\
(0.175)\end{array}$ & $\begin{array}{c}2.469 \\
(0.116)\end{array}$ \\
\hline CVaR & $\begin{array}{c}H_{0} \\
(0.965)\end{array}$ & $\begin{array}{c}H_{0} \\
(0.428)\end{array}$ & $\begin{array}{c}H_{0} \\
(0.637)\end{array}$ & $\begin{array}{c}H_{0} \\
(1.000)\end{array}$ & $\begin{array}{c}H_{0} \\
(0.353)\end{array}$ & $\begin{array}{c}H_{0} \\
(0.281)\end{array}$ & $\begin{array}{c}H_{0} \\
(0.648)\end{array}$ & $\begin{array}{c}H_{0} \\
(0.107)\end{array}$ & $\begin{array}{c}H_{0} \\
(0.349)\end{array}$ & $\begin{array}{c}H_{0} \\
(0.772)\end{array}$ & $\begin{array}{c}H_{0} \\
(0.997)\end{array}$ & $\begin{array}{c}H_{0} \\
(0.788)\end{array}$ & $\begin{array}{c}H_{0} \\
(0.478)\end{array}$ & $\begin{array}{c}H_{0} \\
(0.995)\end{array}$ & $\begin{array}{c}H_{0} \\
(0.423)\end{array}$ \\
\hline VaR Dur. & $\begin{array}{r}-91.549 \\
(0.113) \\
\end{array}$ & $\begin{array}{r}-96.231 \\
(0.846) \\
\end{array}$ & $\begin{array}{c}-123.256 \\
(0.522) \\
\end{array}$ & $\begin{array}{c}-123.243 \\
(0.981) \\
\end{array}$ & $\begin{array}{c}-118.862 \\
(0.757)\end{array}$ & $\begin{array}{r}-91.549 \\
(0.770) \\
\end{array}$ & $\begin{array}{c}-118.875 \\
(0.844) \\
\end{array}$ & $\begin{array}{c}-109.963 \\
(0.804) \\
\end{array}$ & $\begin{array}{c}-100.873 \\
(0.672)\end{array}$ & $\begin{array}{r}-86.796 \\
(0.910) \\
\end{array}$ & $\begin{array}{c}-123.256 \\
(0.480) \\
\end{array}$ & $\begin{array}{c}-114.448 \\
(0.615) \\
\end{array}$ & $\begin{array}{r}-81.967 \\
(0.741) \\
\end{array}$ & $\begin{array}{c}-123.243 \\
(0.105) \\
\end{array}$ & $\begin{array}{c}-127.593 \\
(0.220)\end{array}$ \\
\hline
\end{tabular}



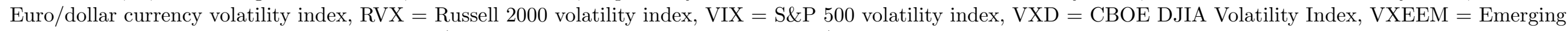

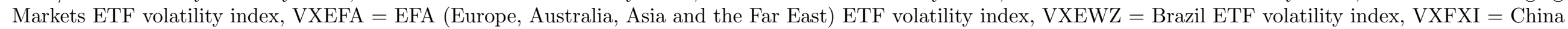

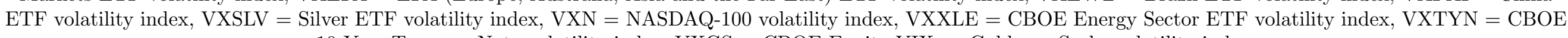
10-Year Treasury Note volatility index, VXGS = CBOE Equity VIX on Goldman Sachs volatility index. 